\title{
Geologic Map of the Central-Southeast Flank of Mauna Loa Volcano, Island of Hawai'i, Hawaii
}

By Frank A. Trusdell and John P. Lockwood

Pamphlet to accompany

Scientific Investigations Map 2932-B

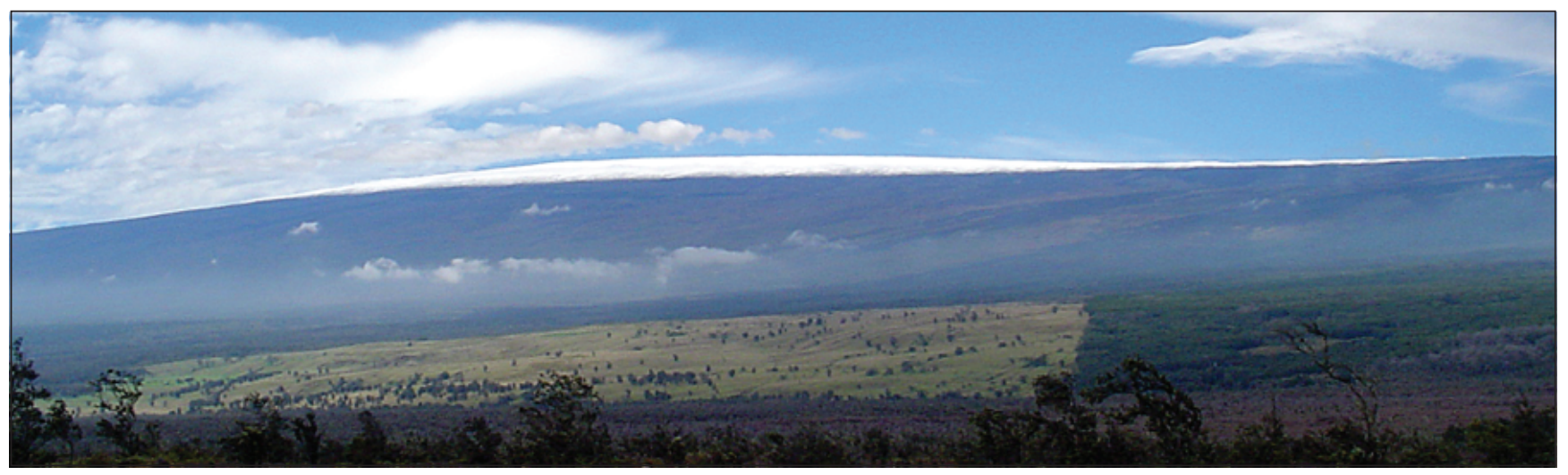

Central-southeast flank of Mauna Loa volcano, Island of Hawai'i, Hawaii. Photograph by Frank A. Trusdell, U.S. Geological Survey. 


\title{
U.S. Department of the Interior \\ DAVID BERNHARDT, Secretary
}

\author{
U.S. Geological Survey \\ James F. Reilly II, Director
}

U.S. Geological Survey, Reston, Virginia: 2019

For more information on the USGS - the Federal source for science about the Earth, its natural and living resources, natural hazards, and the environment-visit https://www.usgs.gov or call 1-888-ASK-USGS.

For an overview of USGS information products, including maps, imagery, and publications,

visit https://store.usgs.gov.

Any use of trade, firm, or product names is for descriptive purposes only and does not imply endorsement by the U.S. Government.

Although this information product, for the most part, is in the public domain, it also may contain copyrighted materials as noted in the text. Permission to reproduce copyrighted items must be secured from the copyright owner.

Suggested citation:

Trusdell, F.A., and Lockwood, J.P., 2019, Geologic map of the central-southeast flank of Mauna Loa volcano, Island of Hawai'i, Hawaii: U.S. Geological Survey Scientific Investigations Map 2932-B, pamphlet 23 p., 2 sheets, scale 1:50,000, https://doi.org/10.3133/sim2932B.

ISSN 2932-1311 (print)

ISSN 2932-132X (online) 


\section{Contents}

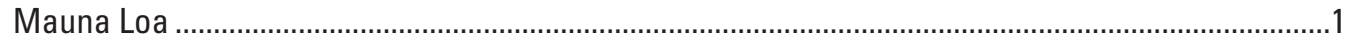

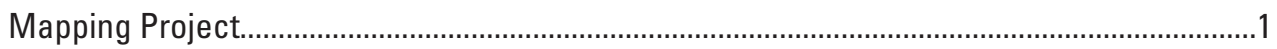

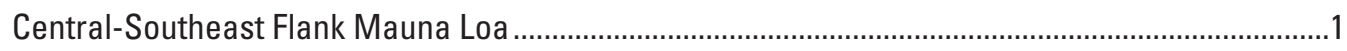

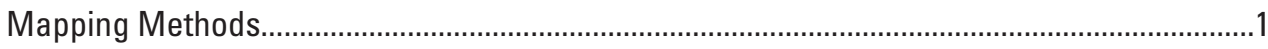

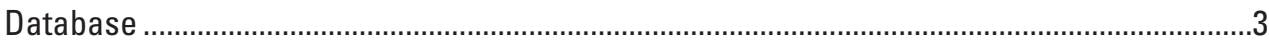

Acknowledgments

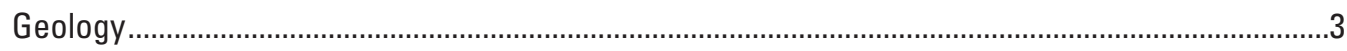

Central-Southeast Flank Mauna Loa ...................................................................................

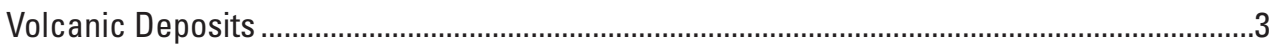

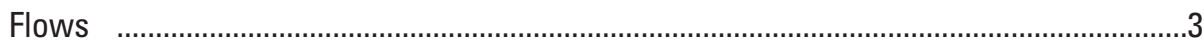

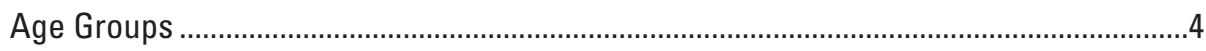

Age Group 0 (Historical period: A.D. 1843 and younger) ............................................

Age Group 1 (pre-A.D. 1843-1,000 yr B.P.) ........................................................

Age Group 2 (1,000-2,000 yr B.P.) ....................................................................

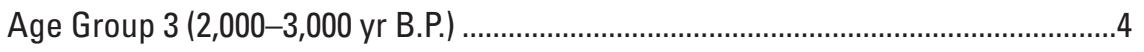

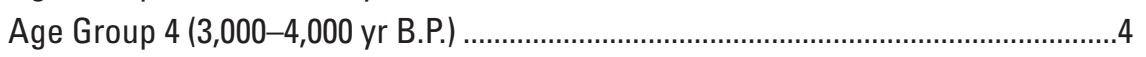

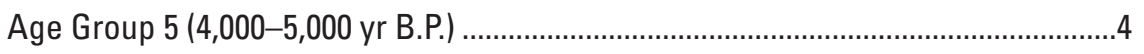

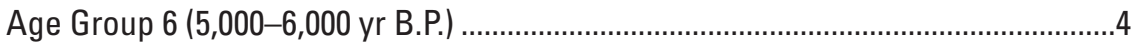

Age Group 7 (6,000-7,000 yr B.P.; not in map area) ……….................................5

Age Group 8 (7,000-8,000 yr B.P.) ................................................................

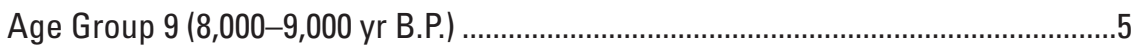

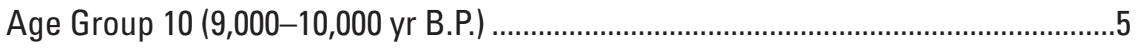

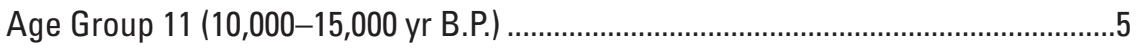

Age Group 12 (15,000-20,000 yr B.P.; not in map area) ........................................

Age Group 13 (20,000-30,000 yr B.P.) .................................................................

Age Group 14 (30,000-100,000 yr B.P.; not in map area) ........................................

Age Group 15 (>100,000 yr B.P.) .....................................................................

Surficial Sedimentary Deposits .......................................................................................

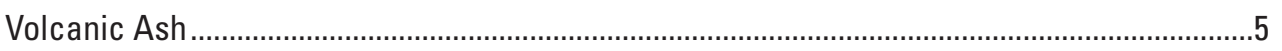

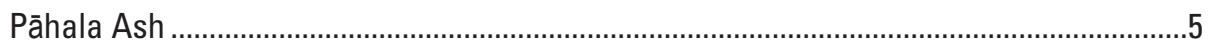

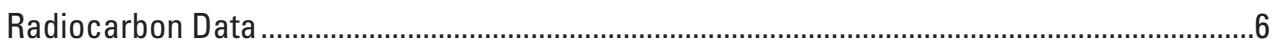

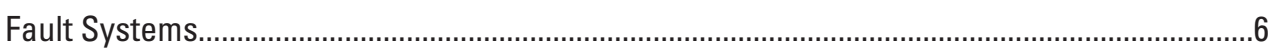

Description of Map Units.........................................................................................................

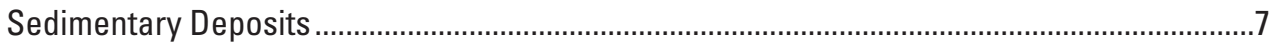

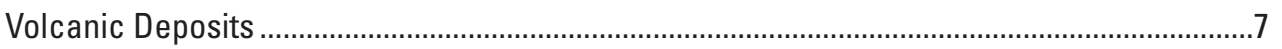

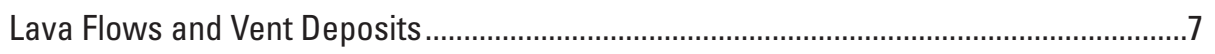

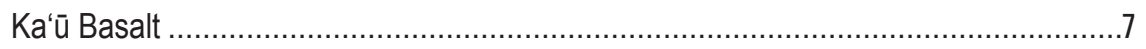

Age Group 0 (A.D. 1843 and younger; Holocene) ...........................................

Age Group 1 (pre-A.D. 1843-1,000 yr B.P.; Holocene) .......................................

Age Group 2 (1,000-2,000 yr B.P.; Holocene) ...............................................

Age Group 3 (2,000-3,000 yr B.P.; Holocene) ................................................10

Age Group 4 (3,000-4,000 yr B.P.; Holocene) ..............................................11

Age Group 5 (4,000-5,000 yr B.P.; Holocene) ................................................12

Age Group 6 (5,000-6,000 yr B.P.; Holocene) ...............................................12

Age Group 7 (6,000-7,000 yr B.P.; Holocene) ...............................................13

Age Group 8 (7,000-8,000 yr B.P.; Holocene) ..............................................13

Age Group 9 (8,000-9,000 yr B.P.; Holocene) .................................................13

Age Group 10 (9,000-10,000 yr B.P.; Holocene) ….........................................13 
Age Group 11 (10,000-15,000 yr B.P.; Holocene and Pleistocene) ..................14

Age Group 12 (15,000-20,000 yr B.P.; Pleistocene) ............................................14

Age Group 13 (20,000-30,000 yr B.P.; Pleistocene) ............................................14

Kahuku Basalt ..................................................................................................

Age Group 14 (30,000-100,000 yr B.P.; Pleistocene) ......................................15

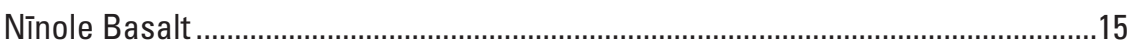

Age Group 15 (>100,000 yr B.P.; Pleistocene) ...............................................15

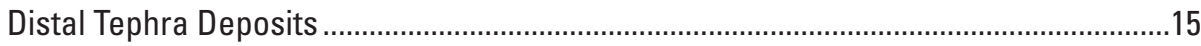

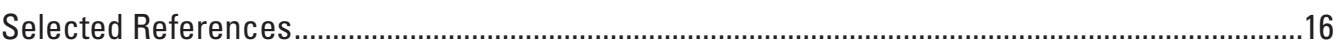

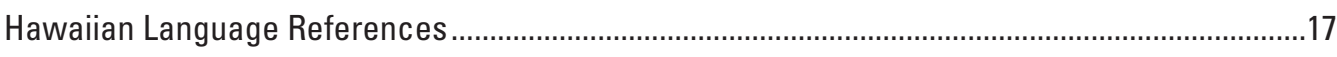

Appendix

\section{Tables}

1. Summary statistics of historical (after A.D. 1843) eruptions on the central-southeast flank of Mauna Loa, Island of Hawai'i, Hawaii.............................................................

2. Radiocarbon ages of samples from the central-southeast flank of Mauna Loa volcano, Island of Hawai'i, Hawaii ..........................................................................18

3. Explanation of map unit labels, colors, and patterns for lava flows and vent deposits on Mauna Loa, Island of Hawai'i, Hawaii ..................................................................sheet 1

\section{Figures}

1. Map showing five subaerial volcanoes forming Island of Hawai'i, structures on Mauna Loa, and 7.5-minute topographic quadrangles covering Mauna Loa............................2 


\title{
Geologic Map of the Central-Southeast Flank of Mauna Loa Volcano, Island of Hawai' $i$, Hawaii
}

\author{
By Frank A. Trusdell and John P. Lockwood
}

\section{Mauna Loa}

Mauna Loa, the largest volcano on Earth, has erupted 33 times since written descriptions became available in 1832. Some eruptions began with only brief seismic unrest, while others followed several months to a year of increased seismicity. Once underway, its eruptions can produce lava flows that may reach the sea in less than $24 \mathrm{hrs}$, severing roads and utilities. For example, lava flows erupted from the Southwest Rift Zone (SWRZ) in 1950 advanced at an average rate of $9.3 \mathrm{~km} / \mathrm{hr}$; all three lobes reached the ocean within approximately $24 \mathrm{hr}$ (Finch and Macdonald, 1953). Near the eruptive vents, the flows must have traveled even faster. In terms of eruption frequency, pre-eruption warning, and rapid flow emplacement, Mauna Loa has great volcanic-hazard potential for the Island of Hawai' $i$. Volcanic hazards on Mauna Loa may be anticipated, and risk substantially mitigated, by documenting the past activity to refine our knowledge of the hazards and by alerting the public and local government officials of our findings and their implications for hazards assessments and risk.

\section{Mapping Project}

The Mauna Loa project is generating detailed geologic maps and associated digital databases for the subaerial volcanic rocks of Mauna Loa (fig. 1). The temporal and spatial records of eruptive activity, traceable to approximately 30,000 yr B.P., provides a geologic framework for evaluating eruptive processes at large basaltic shield volcanoes and determining the long-term frequency and style of Mauna Loa eruptions. This framework can then be used as a guide for volcanic-hazard appraisals and land-use decisions (Trusdell, 1995).

The subaerial volcanic geology of Mauna Loa (fig. 1) is being mapped and digitally compiled on five maps at 1:50,000 scale, to show the extent of surface flows. Approximately 500 flows have been identified and their attributes compiled in a large database. This temporal and spatial record of eruptive activity for the last 30,000 years provides a geologic framework to interpret the long-term frequency and style of Mauna Loa eruptions. These data permit quantitative analysis of the distribution of eruptive products through time and improve evaluation of volcanic risk (Trusdell, 1995).

\section{Central-Southeast Flank Mauna Loa}

The map of the central-southeast flank of Mauna Loa shows the distribution and relations of volcanic and surficial sedimentary deposits. It incorporates previously reported work published in generalized small-scale maps (Lockwood and Lipman, 1987; Lockwood, 1995; Wolfe and Morris, 1996a).

\section{Mapping Methods}

Geological mapping was done by using vertical aerial photos taken in 1977 and 1978. Extensive fieldwork required walking the contacts to distinguish individual flow units and intraflow boundaries, including gradational morphologic transitions between pāhoehoe and ' $a$ ' $\bar{a}$ flows. Where the terrain and jungle obscured contacts, we created a grid pattern of transects. The ensuing contacts were extrapolated between transects from aerial photo interpretation and from geological and botanical inferences. Details from aerial photos were transferred to a 1:24,000-scale base, using a photogrammetric stereoplotter (Kern model PG-2), scanned, and digitized with ArcInfo software to create the digital database.

Reliably correlating discontinuous exposures through heavily vegetated areas is a major challenge on a volcano that consists entirely of compositionally similar basalt. Criteria for correlation include phenocryst size, morphology, and proportion; groundmass texture; vesicle shape; vesicle linings (magnesioferrite); flow morphology; paleomagnetic pole directions; rock chemistry; and varied evidence on relative and absolute ages. Paleomagnetic poles are an indispensable tool for making correlations between flows over large distances and, especially, through dense jungle. Individual flows typically change from pāhoehoe near the vent to 'a'ā downslope, especially for high-discharge eruptions; low-discharge eruptions may result in the distal emplacement of pāhoehoe through efficient lava-tube systems.

The pre-1868 lava flows and tephra deposits are divided into 15 age groups by several methods. The map is largely chronostratigraphic. About half the flows were dated directly (102 radiocarbon ages), using carbonized organic material recovered from beneath flows (Lockwood and Lipman, 1980). For undated flows, relative ages are assigned on the basis of rock and mineral weathering or alteration, soil and tephra accumulation, vegetative cover, and stratigraphic relations with 


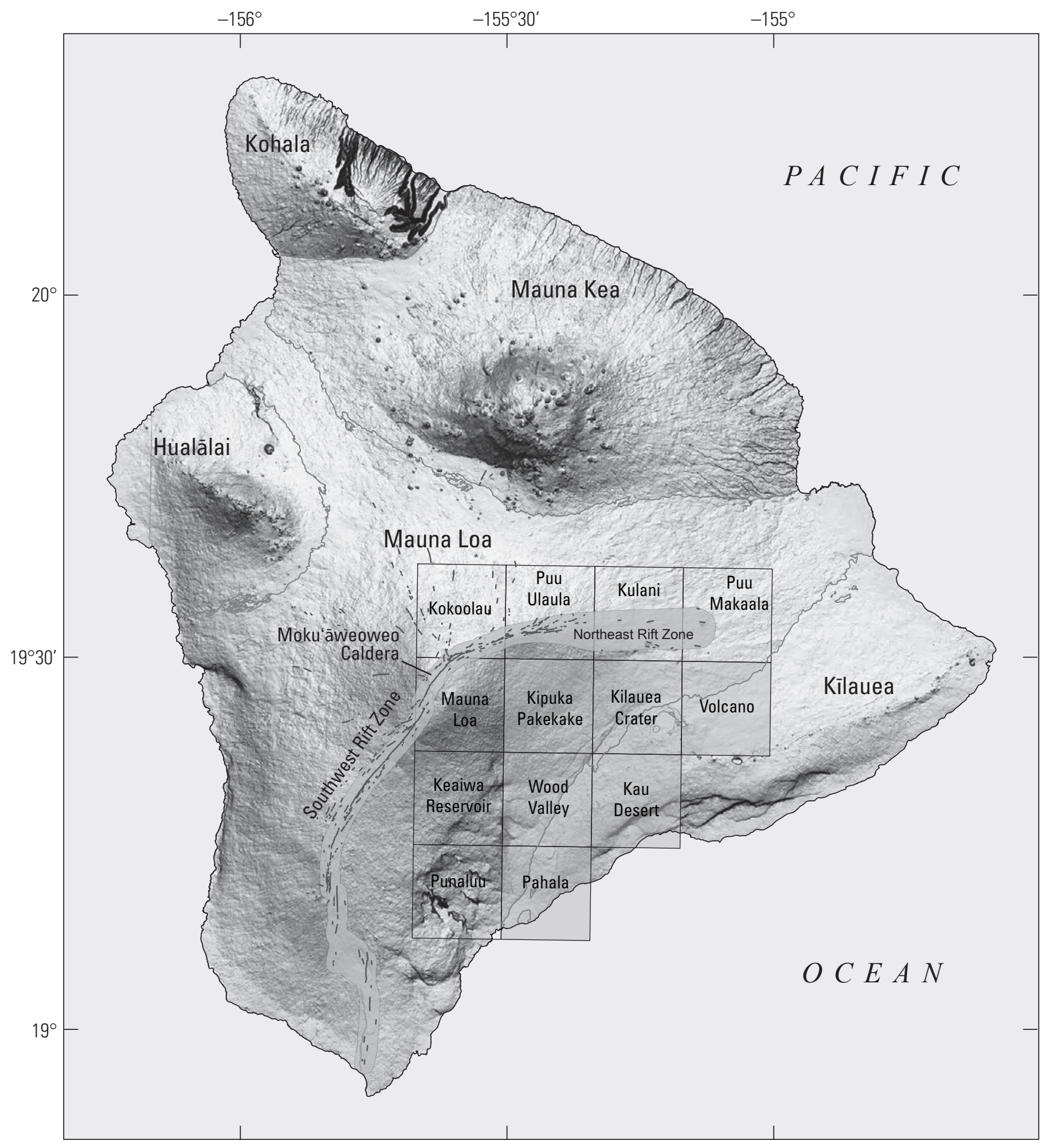

Figure 1. Map showing five subaerial volcanoes forming Island of Hawai'i, structures on Mauna Loa, and 7.5-minute topographic quadrangles in (shaded) and adjacent to map area.

adjoining dated flows. Surface color is an indirect indicator of age (Lipman, 1980, table 1). Young lava flows are initially black. As the rock is exposed to direct sunlight and becomes increasingly weathered, its color changes from black to dull black, then progresses to gray, brown, tan, orange, and, finally, reddish hues. The longer rock is weathered, the greater the color progression.
Lipman and Swenson (1984) used this color scheme effectively to tentatively classify the ages of eruptive units within limited areas. The utility of this technique is influenced by elevation, rainfall, and shielding by forest and tephra cover. Soil and tephra accumulation are also an indirect indicator of age. The thickness of tephra also varies with proximity to the contributing source(s). 


\section{Database}

The digital database contains all information in the printed publication at 1:50,000 scale, but it is accurate to 1:24,000 scale. A unique three-digit flow identification number (FID; for example, FID 831) is assigned to each flow unit mapped on Mauna Loa. The FIDs are unique descriptors in the database and are included in the Description of Map Units, as well as in the Correlation of Map Units. The database contains information on flow morphology, approximate age, exact age, mineralogy, data quality, unit names, rock chemistry, and any existing overburden type. Access the database for this map at https://doi.org/10.3133/sim2932B.

\section{Acknowledgments}

A great many individuals have contributed to the body of knowledge that has made this geologic map possible. We thank Meyer Rubin and Jack McGeehin and those who have worked in their laboratory for radiocarbon age determinations. Duane Champion conducted the paleomagnetic studies to test correlations of several geologic units. Assistants in geologic mapping of the central-southeast flank include Cheryl Gansecki, Jerome Amore, Jim Wise, Tim Tierney, and Lisa Peterson. People who worked as archivists of the geologic samples and charcoal samples include Margery Summers, Toni Thompson, Ramona Navarette, and Vicki Taylor. Superintendents of Hawaii Volcanoes National Park permitted work on the northeast rift. Thorough and helpful reviews of the map and text by Carl Thornber and Edward Wolfe resulted in many improvements in presentation.

\section{Geology}

\section{Central-Southeast Flank Mauna Loa}

Although most Mauna Loa eruptions begin in the summit area at the 12,000-ft elevation (Lockwood and Lipman, 1987), the central-southeast flank has not been the source of any activity. All flows originated from the summit or the upper reaches of the Northeast Rift Zone (NERZ) or the Southwest Rift Zone (SWRZ), shown in figure 1. The NERZ was the source of eight flank eruptions since 1843. The NERZ extends from the 13,680-ft-high summit towards Hilo (population $\sim 43,000$; second-largest city in State of Hawaii). The northern portion of the map area is built entirely on flows erupted from the NERZ. The SWRZ extends from the summit towards Kalae (South Point) at sea level. The southern portion of the map area is built entirely on flows erupted from the SWRZ.

The map area extends from the 10,350-ft elevation high on Mauna Loa's east flank toward the Hawaii Volcanoes National Park and the town of Volcano (population 2,500 ) in the northeast. At the south boundary of the map area is the town of Pāhala (population 1,350). This map includes areas adjacent to and downslope of the NERZ and regions east of and directly downslope of Moku'āweoweo, Mauna Loa's summit caldera (fig. 1).

In general, the northern part of the map, about 40 percent of the map area, is dominated by flows from the middle and upper reaches of the NERZ. The southern part contains flows from the upper reaches of the SWRZ ( $2 \%$ of the map area); flows are generally narrow flow lobes.

One of the most significant findings, based on detailed geologic mapping and dating of lava flows, is that vast sheets of pāhoehoe originated from the summit of the volcano. The sustained summit activity, which lasted for about 900 years, occurred between A.D. 100 and 1,000. Flows from this period blanketed the southeast flank and reached the sea near Punalu'u.

Both morphologic flow types, 'a'ā and pāhoehoe, can be found. The center of the map, approximately 58 percent of the map area, contains flows from the summit of Mauna Loa. In contrast to the rift zones, the flows derived from the summit caldera form voluminous, broad, expansive sheets of pāhoehoe that cover large areas. 'A ' $\bar{a}$ occurs in this area but is inconsequential when compared to the pāhoehoe.

The geologic mapping and the radiocarbon ages indicate that there was a period of sustained summit activity from about 2,000 to 1,300 yr B.P. Lava flows of this age cover more than 75 percent of the area directly downslope from the summit. There are a few kippuka of older flows, but they are limited in number and extent.

\section{Volcanic Deposits}

\section{Flows}

The map encompasses $506 \mathrm{~km}^{2}$ of the southeast flank (fig. 1) of Mauna Loa from 10,350-ft elevation to sea level. It shows the distribution of eruptive units separated into 15 age groups ranging from a period greater than 50,000 yr B.P. to A.D. 1984.

Pāhoehoe, which covers more than $60 \%$ of the map area, is characterized by bulbous, smooth, and ropy surfaces, and the general topography can be described as hummocky. Lava tubes are common features in pāhoehoe flows. Most ' $a$ 'a flows also start as pāhoehoe flow types near the vents and transition to ' $a$ 'a downslope.

'A' $\bar{a}$ flows are generally thicker and form broader units than pāhoehoe flows. 'A' $\bar{a}$ flows are characterized by rubbly and (or) clinkery surfaces with a rough texture; they are typically 3 to $15 \mathrm{~m}$ thick.

Effusion rates and slope influence lava morphology. High effusion rates, combined with steep slopes, usually generate 'a'ā. Moderate to low effusion rates typically produce pāhoehoe. Not surprisingly, ' $a$ 'a is abundant in the region, which has the highest effusion rates and some of the steepest slopes of any sector of Mauna Loa (Trusdell, 1995). The relation between high effusion rates and steep slopes has momentous implications for volcanic hazards and flow-advance rates. Historical flows from the SWRZ have reached the sea in a matter of hours to days (see individual eruption narratives in the Age Group 0 section for specific details). 
Table 1. Summary statistics of historical (after A.D. 1843) eruptions on the central-southeast flank of Mauna Loa, Island of Hawai'i, Hawaii.

[S, Summit; NE, Northeast Rift Zone; SW, Southwest Rift Zone]

\begin{tabular}{|c|c|c|c|c|c|c|c|c|}
\hline Year & $\begin{array}{l}\text { Eruption begins } \\
\text { (month/day) }\end{array}$ & $\begin{array}{c}\text { Summit } \\
\text { activity } \\
\text { (days) }\end{array}$ & $\begin{array}{c}\text { Flank } \\
\text { activity } \\
\text { (days) }\end{array}$ & $\begin{array}{c}\text { Eruptive area of } \\
\text { volcano }\end{array}$ & $\begin{array}{c}\text { Area covered } \\
\qquad\left(\mathrm{km}^{2}\right)\end{array}$ & $\begin{array}{c}\text { Volume } \\
\left(\mathbf{k m}^{3}\right)\end{array}$ & $\begin{array}{l}\text { Error in estimate } \\
\text { (percent) }\end{array}$ & $\begin{array}{l}\text { Closest reach } \\
\text { to Kīlauea } \\
\text { (km) }\end{array}$ \\
\hline 1984 & March 25 & $<1$ & 22 & S, NE & 48 & 0.220 & \pm 20 & 17.0 \\
\hline 1880 & November 5 & 0 & 280 & $N E, S W$ & 51 & 0.130 & \pm 20 to 40 & 3.5 \\
\hline Total & & & & & $99 \mathrm{~km}^{2}$ & $0.35 \mathrm{~km}^{3}$ & & \\
\hline
\end{tabular}

Vesicles are present in both pāhoehoe and 'a'ā flows. In 'a'a flows, vesicles are generally fewer in number and volume $(<35 \%)$, irregularly distributed, commonly deformed and subangular in shape, and larger in size than in pāhoehoe flows. In contrast, vesicles in pāhoehoe flows are smaller, more abundant, and voluminous (40-60\%), moderately distributed to well distributed, and spherical to subrounded in form.

\section{Age Groups}

The age groups are arbitrary boundaries created by the authors. They are broken down into 1,000-year intervals until the latter age groups. The larger age groups represent time periods greater than 1,000 years. The age groups are defined based on radiocarbon years. Unless the flows are dated, the reliability of age determinations decreases with increasing age.

\section{Age Group 0 (Historical period: A.D. 1843 and younger)}

Lava erupted from A.D. 1880 to 1984 covers 1.1 percent of the map area (table 1). Eruptions occurred in 1880-81 and 1984. Soil or ash cover is absent except in forested areas, and surficial glass is common.

A.D. 1984-The 1984 eruption began on March 25 and continued for 22 days. It was Mauna Loa's fifth longest historical NERZ eruption; the erupted volume is $220 \times 10^{6} \mathrm{~m}^{3}$ (Lockwood and others, 1985). Much of the lava is ' $a$ 'a $\bar{a}$. The vents were distributed along a $15-\mathrm{km}$ segment of the NERZ between 9,350- and 12,400-ft elevation. Most fissures are north of the map area at higher elevations. The main fissure is located at approximately 9,600-ft elevation. The fissure that fed the flow in the map area is located at 11,185-ft elevation. The flows from this eruption came within $17 \mathrm{~km}$ of Kîlauea.

A.D. 1880-81-The eruption of 1880-1881 began on May 1, when a small, short-lived eruption at Mauna Loa's summit heralded the beginning of an eruptive sequence that was followed 6 months later by a voluminous flank eruption. This flank eruption would eventually threaten the Hilo area. The flank phase of the eruption began on November 5, 1880 . The outbreak was located at the 11,000-ft elevation, about

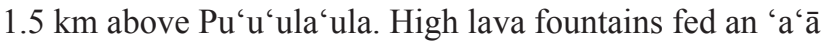
flow that moved swiftly down the north flank (north of the map area). Another branch of ' $a$ 'a flowed southeast, stopping within $3.5 \mathrm{~km}$ of Kīlauea Volcano. By early June, the flow was within $8 \mathrm{~km}$ of Hilo, and concern mounted. On June 26, 1881, the flow entered stream channels above Hilo and appeared to accelerate. By August 10, 1881, all forward progress ceased.

\section{Age Group 1 (pre-A.D. 1843-1,000 yr B.P.)}

Spatter and flows are typically slightly weathered and have negligible overlying soil or tephra except in forested areas. Surficial black glass is common. Eight flows have radiocarbon ages. All flows of Age Group 1 originate from the NERZ. Eruptions from this period cover approximately 20 percent of the map area.

\section{Age Group 2 (1,000-2,000 yr B.P.)}

Spatter and flows typically have some overlying soil or tephra at lower elevations, and any surficial glass shows slight mechanical degradation and color lightening to gray hues. Thirteen of twenty-five flows have radiocarbon ages. Eruptions from this period cover nearly 48.5 percent of the map area.

\section{Age Group 3 (2,000-3,000 yr B.P.)}

Spatter and flows are mildly weathered, and surficial glass is locally preserved. Four of ten flows have radiocarbon ages. Eruptions from this period cover 4.7 percent of the map area.

\section{Age Group 4 (3,000-4,000 yr B.P.)}

Spatter and flows are moderately weathered, and surficial glass is preserved only in protected places. One of twelve flows has a radiocarbon age. Eruptions from this period cover 2.4 percent of the map area.

\section{Age Group 5 (4,000-5,000 yr B.P.)}

Spatter and flows are moderately weathered, surficial glass is rare, and upper surfaces have moderate mechanical degradation. These flows commonly have as much as $0.4 \mathrm{~m}$ of overlying soil or ash when in close proximity to Kîlauea Volcano. One flow of eight has a radiocarbon age. Eruptions from this period cover 1.9 percent of the map area.

\section{Age Group 6 (5,000-6,000 yr B.P.)}

These rocks are increasingly weathered, surficial glass is gone, and upper surfaces have open vesicle texture. Units are typically covered with $0.2-0.3 \mathrm{~m}$ of ash or soil, especially at lower elevations. Eruptions from this period cover much less than 1 percent of the map area. 


\section{Age Group 7 (6,000-7,000 yr B.P.; not in map area)}

Flows with dates of 6,000-7,000 radiocarbon yr B.P. were not identified within the map area. With so many undated flows, a few could fall into this age category. The absence of dates in this range suggests that eruptive activity may have been limited to the summit (lava lake activity) or the volcano's submarine flanks during this time interval (Lockwood, 1995).

\section{Age Group 8 (7,000-8,000 yr B.P.)}

The flows are weathered; upper surfaces have open-vesicle texture and are broken, and orange surfaces occur at higher elevations. Ash has accumulated in low areas. This age group is represented by a single dated flow. Eruptions from this period cover 2.1 percent of the map area.

\section{Age Group 9 (8,000-9,000 yr B.P.)}

The flows are deeply weathered, showing red-orange surfaces at higher elevations; mechanical disintegration of upper surfaces is almost complete. Ash has accumulated in low areas. Two of five flows have radiocarbon ages. Eruptions from this period cover 2.7 percent of the map area.

\section{Age Group 10 (9,000-10,000 yr B.P.)}

These flows and all older age groups are found only at the southeastern portion of the map area; they have been buried by younger flows closer to eruptive vents. Ash and soil fill low-lying areas; accumulations of as much as $0.5-1 \mathrm{~m}$ are common. Surface color approaches red. Three of six flows have radiocarbon ages. Eruptions from this period cover slightly more than 3 percent of the map area.

\section{Age Group 11 (10,000-15,000 yr B.P.)}

These flows have few original surfaces left. Upper surfaces are commonly stained red orange, probably due to hydration of glass. In the wet, windward regions, the rock is soft, and hammer impacts often leave a divot. Olivine is altered, yellow, and (or) brown green and looks slightly flaky. Units of this age have 1-3 m of soil or ash cover. Partly altered groundmass is often a dull gray and appears cryptocrystalline. Two of four flows have radiocarbon ages. Eruptions from this period cover 0.5 percent of the map area.

\section{Age Group 12 (15,000-20,000 yr B.P.; not in map area)}

Flows with dates of 15,000-20,000 were not identified within the map area. These flows have no original surfaces left. Upper surfaces are commonly stained red orange, probably due to hydration of glass. In the wet, windward regions, the rock is yielding and mushy; hydrated glass turns to clay. Olivine appears flaky and (or) cloudy and mostly altered. Units of this age have 2-4 $\mathrm{m}$ of soil and ash cover. Groundmass is altered and lined with alteration products (such as limonite).

\section{Age Group 13 (20,000-30,000 yr B.P.)}

These flows are exposed in drainages and include the only surface exposures of Pāhala Ash (unit pa) southeast of
Nā‘ālehu, at the coast near Kāhilipali Nui, and at the crest of the Kahuku Pali. The flows have no remaining original surfaces. Boundaries between individual flows are blurred. In the wet, windward regions, the rock is mushy; olivine phenocrysts are altered. Four units have radiocarbon ages. Eruptions from this period cover much less than 1 percent of the map area.

\section{Age Group 14 (30,000-100,000 yr B.P.; not in map area)}

These flows are exposed in fault scarps, sea cliffs, and drainages around Pāhala. Flows are commonly overlain by as much as $6 \mathrm{~m}$ of ash. Flows have lost all original surfaces, and boundaries between individual flows are blurred. In wet, windward regions, the rock is mushy; olivine phenocrysts are mostly altered and generally soft. Eruptions from this period cover less about 0.4 percent of the map area.

\section{Age Group 15 (>100,000 yr B.P.)}

Flows with dates of $>100,000 \mathrm{yr}$ B.P. were identified within the map area around Wood Valley. These flows are exposed in valley walls. The unit represents the oldest exposed rocks on Mauna Loa. These rocks are commonly overlain by as much as $6 \mathrm{~m}$ of ash and have no remaining original surfaces.

\section{Surficial Sedimentary Deposits}

Deposits were too small and transient to map. They consist chiefly of colluvial and alluvial deposits of basalt clasts and pebble- to cobble-sized gravel in drainages that occur locally within portions of the map area. We also include under this category unconsolidated sand along the coast.

\section{Volcanic Ash}

\section{Pāhala Ash}

Pāhala Ash includes beds of fallout and surge deposits that represent accumulation of deposits from numerous eruptions. Deposits include glassy ash and lapilli, now mostly altered to clay, crystals, and lithic fragments. Phenocryst abundance is difficult to estimate, owing to chemical decomposition, but ranges from aphanitic to moderately porphyritic, with as much as 8 percent olivine and fewer plagioclase phenocrysts. It is found chiefly in all quadrangles and in adjacent upslope areas, where it overlies lava flows ranging in age from 31,000 to 2,000 yr B.P.

There are two main subdivisions in this group: southern tephra (unit ts) and Pāhala Ash (unit pa). Southern tephra comprises beds of ashfall deposits in the map area. The source of the ashes is unknown but is considered to be primarily from Kîlauea Volcano, with likely contributions from Mauna Loa (Easton, 1987). All ash deposits $\leq 10,000$ yr B.P. are included in this category and cover nearly 12.8 percent of the map area.

The term "Pāhala Ash," named for the town Pāhala, was used with reference to ash deposits found along the northeast rift zone of Mauna Loa, northeast Kîlauea Volcano, and south and southwest of Kîlauea's summit, including the eastern flank 
of Mauna Loa. The bulk of the ash is presumed to be from Kîlauea, although Mauna Loa cannot be excluded as a source.

Pāhala Ash was described by Stone (1926), Stearns and Clark (1930), Wentworth (1938), Stearns and Macdonald (1946), Fraser (1960), Walker (1969), and Easton (1987). The term eventually came to be used for ashes from Kohala to Kalae at South Point. According to Easton (1987), Wolfe (verbal commun., 1986) determined that the ash deposits of Kohala, Waimea, Hāmākua, and North Hilo were derived locally and are chemically distinct from ashes near Kîlauea and on the east flank of Mauna Loa.

Wentworth (1938) and Stearns and Macdonald (1946) describe several sections of Pāhala Ash, yet, a type section was not identified. Easton (1987) proposed two well-exposed sections on the south flank of Killauea Volcano for the type locality of the Pāhala Ash.

The ash is a mixture of yellow-brown palagonite, rare vitric shards, Pele's hair, pumice, and olivine phenocrysts. It is derived from airfall deposits, weathered and reworked ash, and sediments. The ash is composed of mostly sand and silt-sized fractions. Ancient soil horizons are present in some localities.

The appearance of the ash is greatly influenced by climate. In dry areas, it is friable, in places compact, but it is mostly sandy, loose, and dusty. In higher-rainfall areas, the ash appears clay-like. The ash deposits from Ka'alu'alu to Kalae or South Point appear to be loess, reworked and redeposited by wind.

All ashes in the map area that are less than, and equal to, late Pleistocene ( $<16,000$ yr B.P.) are incorporated into unit ts, which identifies a mostly Holocene ash deposit of sufficient thickness to mask the underlying flow(s) or the extent of the flow(s) cannot be mapped with a reasonable degree of certainty. In other places, where we are able to map ash-covered flows, $<16,000$ yr B.P. in age, with a high degree of certainty (see database for contact certainty), we chose to use a plus pattern. The overlying ashes are grouped with unit ts.

Our mapping demonstrates - and previous investigators noted (Stearns and Macdonald, 1946; Easton, 1987) - that the Pāhala Ash was a catch-all for all ash units from northeast Kīlauea Volcano, across Kīlauea's south flank, extending over Mauna Loa to (at least) Kalae to Kahuku Pali. This included ashes of all ages (0.2-25 ka; Stearns and Macdonald, 1946). The periodicity with respect to Pāhala Ash production was more infrequent than was previously recognized.

We are able to show that there have been at least eight ash events, where lava flows separate the younger ash layers (unit ts). Most of the individual ash horizons have not been studied well enough to be used as marker beds over a wide geographic area. We concur with previous investigators that the most likely source is Kîlauea, although Mauna Loa cannot be excluded as a source.

In order for Pāhala Ash to be recognized as a stratigraphic marker, its horizon needs to be recognizable over a large geographic region. Easton (1987) proposed a more restrictive age range of 25-10 ka for Pāhala Ash. Our preference would be to restrict the Pāhala Ash age even further, to approximately 31-16 ka, and possibly older, thereby providing a constraining period of time within which substantial ash accumulation occurred and is preserved, in places, on the flanks of Mauna
Loa. The accumulated ash can then be used as a stratigraphic marker across a wide region. Unfortunately, this means that most type sections can only be found in drainages, arroyos, sea cliffs, and on top of Ninole Hills above Punalu'u.

\section{Radiocarbon Data}

Radiocarbon is obtained from under flow margins and usually dates the surface flow. This map includes some ages obtained from a vertical section (for example from a waterfall). Flows that are dated, in sections, from charcoal are represented by a solid black square on the map. In a few instances, we were able to obtain charcoal under the surface unit, but not at the contact between adjacent flows. The symbol is found inboard of the contact. In a few of these cases, heavy equipment broke through the flow (at a quarry), and we retrieved charcoal. In other instances, we obtained charcoal from arroyos, and the underlying outcrops were less than $5 \mathrm{~m}^{2}$. Due to the limited exposure, we were not able to adequately characterize these units, and the map units were tiny; we do not show these units.

Table 2 reports 102 radiocarbon ages from 46 lava flows (Kelley, 1979; Kelley and others, 1979; Rubin and others, 1987; Buchanan-Banks and others, 1989; Buchanan-Banks, 1993; this study). Many are conventional ages determined at the U.S. Geological Survey (USGS) laboratory in Reston, Virginia. Thirty-six Accelerator Mass Spectrometer (AMS) ages were analyzed by USGS and other laboratories. For eruptive units at more locations, each age is weighted by the inverse of its variance to yield a mean age (Taylor, 1982).

All ages were calibrated to calendar years, using the CALIB 6.0 Radiocarbon Calibration Program (Stuiver and others, 2005). The calibrated age ranges in table 2 encompass the calendar years possible for a given radiocarbon age at two standard deviations; however, all ages shown on the map are radiocarbon yr B.P. Symbols in table 2 indicate reliability of age for stratigraphic interpretations. Rejected ages are reported in the appendix.

\section{Fault Systems}

The system of normal faults, which occurs on the southeast flank of the volcano, are the Ka'ōiki-Honu'apo Fault System. Faults shown on the map were adapted from Wolfe and Morris (1996a). All faults within the map area are inactive and are draped by unfaulted, younger flows as old as 9,500 yr B.P. The concealed fault scarps are as much as $100 \mathrm{~m}$ high and traceable for as much as $10 \mathrm{~km}$ in an east-northeast direction.

In addition to the concealed faults on the southeast flank, there is a historically active tectonic zone. This area, known as the Ka'ōiki Fault Zone, is in the epicentral region for some recent large tectonic earthquakes. The Ka'ōiki Fault Zone has been active as recently as 1983 and prior to that in 1974 and 1962. In 1983, there was a $6.6 \mathrm{M}_{\mathrm{L}}$ earthquake on the southeast flank of Mauna Loa and there was discernible movement along this fault system. Ground rupturing took place, and displacements measured as large as $1.5 \mathrm{~m}$ in 1983 and as large as $0.5 \mathrm{~m}$ in 1974. Unlike the concealed faults of the Ka'öiki-Honu'apo Fault 
System, which are buried normal faults, ground breakage in the Ka'ōiki Fault Zone is characterized by recent, left-stepping, en echelon ground cracks created by strike-slip motion along a fault system that strikes N. 40-50 E. (Jackson and others, 1992).
In the Wood Valley quadrangle, there are two graben that extend upslope. One graben cuts units p2e11 and p3e4; the second is found entirely within unit p3e4. Faults shown in the map area are adopted from Wolfe and Morris (1996a).

\section{DESCRIPTION OF MAP UNITS}

[Small areas on the printed or plotted map are not labeled, to avoid obscuring data; use unit color or the database (https:// doi.org/10.3133/sim2932B) for unit identification. The simplified map unit label is not unique and provides quick access to flow morphology, flow age group, phenocryst mineralogy, and flow number in an age group (table 3, sheet 1); this nonunique unit label may be used for an entirely different unit on a different flank of Mauna Loa. We use the term "phenocryst" for any mineral $\geq 1 \mathrm{~mm}$ in maximum diameter. Pyroxene is not an abundant phenocryst in Mauna Loa lava flows and, therefore, it is not included in phenocryst mineralogy. Multiple labels for a unit are listed with the most abundant lithology first. In addition to the map unit label, a unique, three-digit, flow identification number (FID; for example, FID 831) is assigned to each mapped flow unit to facilitate use of the database; therefore, the FID is essential as a unique descriptor for unit identification in the database. No Age Group 7, 12, or 14 units were identified in the map area]

\section{SEDIMENTARY DEPOSITS}

$\mathrm{mf}$

Is

Mudflow deposits of A.D. 1868 (Holocene) - In A.D. 1868, a large destructive earthquake caused a landslide in the back of Wood Valley and south of Ipu'u Ridge. Rock lubricated by wet ash tumbled down from the hillside. Stearns and Macdonald (1946) originally mapped the mudflow, which we have included on our map. The original extent of the mudflow is no longer evident, because sugar cane companies spread out the deposits to enhance productivity

Landslide deposits (Holocene) - Landslides of unknown age, including some of the 1868 mudflow, are shown on the map in the region of Wood Valley. In recent mapping, we were only confident of landslide deposits at the foot of the valley walls and short distances downslope. The bulk of the deposits were spread out by sugar cane companies as media to grow cane

\section{VOLCANIC DEPOSITS}

\section{LAVA FLOWS AND VENT DEPOSITS}

\section{Ka' ${ }^{\prime} \overline{~ B a s a l t}$}

The Ka' $\bar{u}$ Basalt includes historic and prehistoric members. The prehistoric units range in age from pre-A.D. 1843 to 30,000 yr B.P. The Ka' $\overline{\mathrm{u}}$ Basalt consists of tholeiitic basalt, vent deposits, and lava flows. The flows are mostly aphanitic and some have variable amounts of olivine and plagioclase phenocrysts. Pyroxene is rare in hand specimen. All but one of the map units are members of the Ka' $\bar{u}$ Basalt.

$$
\text { Age Group } 0 \text { (A.D. } 1843 \text { and younger; Holocene) }
$$

a0a1

a0b2

a1g1
A.D. 1984 flow - Aphanitic ' a'ā, with $<1 \%$ olivine phenocrysts $1-2 \mathrm{~mm}$ in size. Vents were distributed along 15-km segment of NERZ between 9,350- and 12,400-ft elev. Most fissures are north and west of map area some at higher elevations. A flow from this eruption enters the north margin of the map area. The eruptive fissure that fed this flow is located at the 11,185-ft elev. FID 783

A.D. 1880-81 flow-Flow is fresh and glassy, with 1-3\% clear olivine phenocrysts and abundant, inconspicuous plagioclase microphenocrysts. An 'a'ā flow enters from the north edge of the map and extends $\sim 13 \mathrm{~km}$ in a southeasterly direction diagonally across the map. FID 787

Age Group 1 (pre-A.D. 1843-1,000 yr B.P.; Holocene)

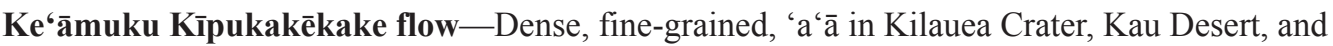
Kipuka Pakekake quadrangles. Groundmass is sparkly, dark, and feldspathic. Small olivine phenocrysts $(<1 \%)$ are widely scattered; $1-2 \%$ plagioclase is present as fine laths. Age, $288 \pm 36$ radiocarbon yr B.P. FID 800 
$\mathrm{p} 1 \mathrm{k} 2, \mathrm{a} 1 \mathrm{k} 2$, m1k2

p1a3, a1a3 m1a3

p1g4

a1k5, m1k5, $\mathrm{p} 1 \mathrm{k} 5$

p116, a116

$a 1 b 7, p 1 b 7$

p1e8, a1e8

a1i9, p1i9

a2g1

p2b2

p2i3, a2i3, $\mathrm{m} 2 \mathrm{i} 3$

p2a4, a2a4

p2i5, a2i5
Kīpukamauna'iu flow—Pāhoehoe and 'a'ā, in contact with the lava flow of A.D. 1880, in Kipuka Pakekake quadrangle. Contains dense, well-crystallized, feldspathic groundmass. Surface is medium gray to black. Flow tops, locally glassy, are mostly weathered; surface glass is broken up. Flow contains $0-1 \%$ small olivine phenocrysts and $1-8 \%$ anhedral laths and clots of plagioclase, commonly intergrown with olivine. Vesicles are subrounded, commonly distorted, and may be lined with magnesioferrite. Age, $311 \pm 25$ radiocarbon yr B.P. FID 801

Ke A Po'omoku Lava Flow-Massive pāhoehoe and 'a'ā that flooded Mauna Loa's flank northeast of the caldera and southeast of the rift zone in northwestern Kipuka Pakekake quadrangle. Eruptive fissures of this eruption extend into the NERZ and are found outside of the map area to the northwest. Contains $<1 \%$ olivine phenocrysts in medium-gray, fine-grained feldspathic groundmass. Age, $475 \pm 41$ radiocarbon yr B.P. FID 274

$K^{\top} e^{‘ a ̄ m u k u ~ K i ̄ p u k a k u l a l i o ~ f l o w-D e n s e, ~ d a r k-g r a y, ~ n e a r l y ~ a p h a n i t i c ~ p a ̄ h o e h o e ~ i n ~ n o r t h e a s t e r n ~ K i p u k a ~}$ Pakekake and northwestern Kilauea Crater quadrangles. Flow contains $<1 \%$, widely scattered olivine phenocrysts and 2\% plagioclase phenocrysts. Age, $569 \pm 53$ radiocarbon yr B.P. FID 802

Ke'āmuku Kīpukakulalio east flow-Tube-fed pāhoehoe with some 'a'ā, in Kipuka Pakekake quadrangle. Glass is fresh where protected from mechanical weathering. Contains $2-6 \%$ olivine phenocrysts and from $5-10 \%$ plagioclase as laths, clumps, and intergrowths with olivine. Vesicles are mostly rounded and coated with magnesioferrite. Tree molds are exposed along $\mathrm{Pu}^{\prime} \mathrm{u}^{6} \overline{\mathrm{o}}^{`} \overline{\mathrm{o}}$ Volcano Trail where not covered by ash. Abundant charcoal samples can be found where this unit overlies a5b7 (FID 870). Age, 575 38 radiocarbon yr B.P. FID 799

Keauhou Ranch flow - Large tube-fed pāhoehoe with minor 'a'ā north of Kīpukapuaulu, on Keauhou Ranch in central Kilauea Crater quadrangle. The 6-20\% olivine forms phenocrysts and microphenocrysts; $4-6 \%$ plagioclase mostly microphenocrysts and groundmass. Age, $760 \pm 70$ radiocarbon yr B.P. FID 833

Flow northeast of A.D. 1880 lobe - Mixed 'a'ā and pāhoehoe flows in northeastern Kipuka Pakekake quadrangle. Contains $4 \%$ inconspicuous round olivine phenocrysts. Age, $780 \pm 70$ radiocarbon yr B.P. FID 840

Pu'uwahi picrite flow-Dense picrite in northeastern Kipuka Pakekake and central Kilauea Crater quadrangles. Pāhoehoe and 'a'ā with a medium-gray groundmass, containing 10-20\% clear, fresh olivine phenocrysts as much as $6 \mathrm{~mm}$ across. Weathered surfaces are orange brown, with protruding olivine minerals. Age, $955 \pm 24$ radiocarbon yr B.P. FID 837

Ke'āmuku Kīpukakulalio west flow — Both 'a'ā and pāhoehoe in northwestern Kilauea Crater quadrangle. Flow contains 3-8\% subhedral, sugary olivine phenocrysts and $0-2 \%$ plagioclase phenocrysts. Vesicles are subrounded to elongate and may be magnesioferrite lined. FID 838

$$
\text { Age Group } 2 \text { (1,000-2,000 yr B.P.; Holocene) }
$$

Flow 300 - 'A' a flow in northwest quadrant of Kipuka Pakekake quadrangle. Flow contains $1-2 \%$ olivine microphenocrysts and abundant groundmass plagioclase to $2 \%$ as phenocrysts. The groundmass is dark gray and dense, with abundant plagioclase microlites. Unit overlies p2i3 (FID 298). FID 300

West Wood Valley flow-Flow that forms floor of western side of Wood Valley. A spongy tube-fed pāhoehoe has $0-5 \%$ olivine phenocrysts in light-gray diktytaxitic groundmass. Flow is covered by variable amounts of soil ash that can be as thick as $1.5 \mathrm{~m}$. Primary surfaces with black glass common; glass usually found in protected spots on surface and commonplace on base. Age, 1,281 \pm 66 radiocarbon yr B.P. Unit overlies p2b23 and p2b24 (FIDs 292 and 294). FID 293

Pahuamimi flow-Major unit from summit region of Mauna Loa. Flow traverses Kipuka Pakekake from northwest to southeast in central and northeastern portions of the quadrangle. Flow is most common as tube-fed pāhoehoe. Tumuli are common, as are areas containing slabby pāhoehoe and fluid 'a'ā. Contains 5\% plagioclase as blades and commonly intergrown with olivine. Unit contains $2 \%$ olivine phenocrysts and microphenocrysts. Age, 1,293 \pm 27 radiocarbon yr B.P. Unit overlies a2k13 (FID 347). FID 298

Keakapulu Flat flow-Young-looking tube-fed pāhoehoe unit in north-central Wood Valley and southwestern Kipuka Pakekake quadrangles. Unit has 3-8\% inconspicuous olivine microphenocrysts. Due to their small size, the olivine could be easily overlooked. The groundmass is well crystallized and feldspathic with obvious plagioclase microlites. Unit is covered with as much as $30 \mathrm{~cm}$ of ash. Age, 1,428 \pm 38 radiocarbon yr B.P. FID 297

Kapāpala flow - Tube-fed pāhoehoe in central Wood Valley unit originated from summit. Flow contains $3-8 \%$ olivine phenocrysts and differs from its neighbors in that it has $2-3 \%$ 
p2c6

p2f7

p2e8, a2e8, $\mathrm{m} 2 \mathrm{e} 8$

p2f9

p2b10

a2k11, p2k11

a2a12, p2a12

a2k13, p2k13

p2e14, a2e14

p2b15

p2b16 plagioclase. Upper surfaces usually orange stained and may be topped by a $6-8 \mathrm{~mm}$ glassy rind. Flow is characterized by hummocky terrain. Flow is often overlain by $10-50 \mathrm{~cm}$ of ash. Age, $1,469 \pm 32$ radiocarbon yr B.P. FID 344

Kilohana flow-Tube-fed pāhoehoe found in central Wood Valley quadrangle. This flow is distinctive in that the olivine has two habits: laths and equant phenocrysts. Flow contains $5-15 \%$ olivine phenocrysts and microphenocrysts. The groundmass is well crystallized and feldspathic. Flow has little to no ash cover. Age, 1,507 24 radiocarbon yr B.P. Unit overlies p2c25 (FID 340). FID 301

Waimuku flow_-Large tube-fed pāhoehoe in Wood Valley and Pahala quadrangles. This unit is distinctive in that the flow contains olivine with two habits: equant phenocrysts and laths. Flow has variable amounts of olivine, at $3-20 \%$; flow tops are black and glassy. The groundmass is light gray, well crystallized, microcrystalline. Flow is covered by $10-50 \mathrm{~cm}$ of ash in places. Age, 1,511 \pm 24 radiocarbon yr B.P. Unit is overlain by p2b2 (FID 293). In addition, it overlies p2f9, p2b10, and p2b15 (FIDs 288, 290, and 336). FID 289

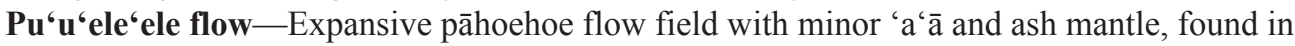
southwestern Kipuka Pakekake and northeastern Wood Valley quadrangles. Flow is distinctive in that olivines protrude through the glassy surface giving the flow a knobby appearance. Flow contains $\sim 20 \%$ olivine and as much as $5 \%$ plagioclase. The olivines range in size from 4-8 $\mathrm{mm}$ and are clear and sugary. Subhedral plagioclase occurs as anhedral phenocrysts and microphenocrysts to $2 \mathrm{~mm}$ and is commonly intergrown with olivine. Vesicles are subrounded and magnesioferrite lined. Age, 1,530 37 radiocarbon yr B.P. FID 346

Ka'ala'ala Gulch flow — Large tube-fed pāhoehoe in western Wood Valley and Ka'ala'ala Gulch. This extensive pāhoehoe is one of many similar flows of summit origin in this region. The unit contains $2-8 \%$ olivine phenocrysts and microphenocrysts in a diktytaxitic groundmass. The flow is covered by $10-50 \mathrm{~cm}$ of ash in places. Age, 1,574 \pm 25 radiocarbon yr B.P. FID 288

Kapāpala Ranch flow-Tube-fed pāhoehoe, in Wood Valley quadrangle, contains 1-5\% olivine. Also, found at the site of Kapāpala Ranch headquarters. Flow is covered with a veneer of ash as thick as $0.5 \mathrm{~m}$. In low slope areas, tumuli and hummocky terrain dominate flow character. Flow tops orange stained with original flow surfaces common. Black vitreous glass only preserved in folds and creases on upper surfaces and glass is common on flow bottom. Age, 1,622 \pm 23 radiocarbon yr B.P. FID 290

Upper Waiākea flow_-Mixed pāhoehoe and 'a'ā flows along the north edge, and in the center of, Kilauea Crater quadrangle. Contains $0-2 \%$ olivine phenocrysts, commonly as intergrowths with plagioclase, and 5-12\% very fine plagioclase as laths and blebs. Vesicles are subrounded, elongate, and commonly magnesioferrite lined. 'A'ā is crumbly and weathered to a yellow orange. The flow is covered with a thin to thick layer of soil and ash; consequently, outcrops range from abundant to rare. This eruption sent flows over both sides of the rift zone, though the bulk of the lava flowed to the northeast. Age, 1,638 32 radiocarbon yr B.P. FID 864

Flow 841 - Aphanitic ' $a$ ' $\bar{a}$, with minor pāhoehoe, found in the central portion of Kipuka Pakekake quadrangle. The ' $a$ 'ā is dense, fine-grained, and feldspathic. Flow is covered by deep soil. Unit overlies p2e14 (FID 343). FID 841

Nāpu'ukūlua Lava Flow - 'A 'a a flow 10-12 m thick with distinctive mineralogy found in northwest quadrant of Kipuka Pakekake quadrangle. Contains $6-8 \%$ plagioclase laths and $\sim 1 \%$ olivine phenocrysts in a dense medium-gray groundmass. Surface color is chocolate brown; minor yellow ash deposited in low areas. Unit overlies p2e14 (FID 343). FID 347

Kauhiuhi flow-Major tube-fed olivine-rich pāhoehoe at junction of Kilauea, Kipuka Pakekake, and Wood Valley quadrangles. This distinctive olivine-rich pāhoehoe has $\sim 20-25 \%$ clear green phenocrysts in a dull gray cryptocrystalline groundmass. The upper flow surface appears to be knobby or warty owing to olivine protruding through the surface glass. The basaltic glass is common but mostly eroded away. Age, $1,640 \pm 150$ radiocarbon yr B.P. Unit is overlain by a2a12 and a2k13 (FIDs 841, 347). FID 343

East Wood Valley flow-Tube-fed pāhoehoe flow, which traverses the eastern portion of Wood Valley. Flow contains 1-3\% olivine phenocrysts in a light-gray, well-crystallized plagioclase microlite-rich groundmass. Covered with variable amounts of ash, $0-1.5 \mathrm{~m}$ thick. Age, 1,708 \pm 50 radiocarbon yr B.P. Unit is overlain by p2b2 and p2f7 (FIDs 293, 289). FID 336

Moa'ula flow-Young-looking spongy pāhoehoe flow between Hi'onamoa and Moa'ula Gulches in Pahala quadrangle. Flow originates from the Southwest Rift Zone of Mauna Loa. The pāhoehoe has $0-2 \%$ olivine in a well-crystallized groundmass. The flow tops are black and glassy. Flow overlain by ash in low-lying areas. Age, 1,824 19 radiocarbon yr B.P. FID 540 
Flow 350 - Pāhoehoe in the northwest corner of Kipuka Pakekake quadrangle. Variable olivine mineralogy $\sim 8-20 \%$, subhedral, blades and phenocrysts. Olivines are dull, light green in color, inconspicuous, and range in size from $0.5-2.5 \mathrm{~mm}$. Anhedral clots of plagioclase and olivine are common at $2-3 \%$. The groundmass is medium gray and feldspathic. The surface color is tan gray; ash cover is thin at $0-0.14 \mathrm{~m}$ and concentrated in low-lying areas. Unit overlies a2a18 (FID 349). FID 350

a2a18, p2a18, m2a18

a2a19, p2a19

a2k20, p2k20

a2k21, p2k21

p2g22, a2g22

p2b23

p2b24

p2c25

a3a1

a3a2, p3a2

a3i3

p3e4, m3e4, a3e4
Kauhiuhi Maluikeao flow-Aphyric pāhoehoe with $<1 \%$ fine olivine phenocrysts in a diktytaxitic, vesicular groundmass. Groundmass is bluish gray, dense, and occasionally feldspathic. Upper surfaces in places weathered to yellow orange; otherwise, color is tan gray. Flow is found in northwest corner of Kipuka Pakekake quadrangle. Age, 1,910 120 radiocarbon yr B.P. Unit is overlain by p2j17 (FID 350). FID 349

Flow 989-Aphanitic flow located in center of adjoining boundaries of Kilauea Crater and Kipuka Pakekake quadrangles. This pāhoehoe has a well-crystallized groundmass that contains plagioclase microlites. Flow is blanketed by $\sim 20 \mathrm{~cm}$ of ash. Surface color is orange gray and original primary surface is almost nonexistent. Unit overlies p2k20 (FID 893). FID 989

Kīpukalō'ihi flow-Blocky 'a'à kīpuka east and southwest of A.D. 1880. Distal end of flow is 20-25 m thick near the boundaries of Kilauea Crater and Kipuka Pakekake quadrangles. Flow contains $4-10 \%$ plagioclase phenocrysts and $1-3 \%$ olivine phenocrysts in a medium-gray groundmass. Olivine commonly intergrown with plagioclase. Flow covered by a minor amount of ash. Unit overlies p2g22 (FID 883). FID 893

Flow 900 - 'A' $\bar{a}$ flow along the west border of Kilauea Crater quadrangle. Flow contains $5 \%$ plagioclase laths as glomerocrysts and $2 \%$ olivine phenocrysts intergrown with plagioclase. The flow exhibits pāhoehoe-like character in places, with slabby plates and toothpaste-like morphologies. Unit overlies p2g22 (FID 883). FID 900

Upper Strip Road flow - Extensive pāhoehoe and related tube system, characterized by bulbous toes, south of Nāpu 'ukūlua in northwestern Kipuka Pakekake and Kilauea Crater quadrangles. Contains $<1 \%$ olivine phenocrysts and $\sim 2 \%$ plagioclase as microphenocrysts and phenocrysts. Vesicles are spherical to subrounded. Age, $1,993 \pm 43$ radiocarbon yr B.P. Unit is overlain by a2k20 and a2k21 (FIDs 893, 900). FID 883

Pi'ikea flow-Pāhoehoe flows that form southwest valley floor and ridge of Wood Valley. Flow comprises multiply bedded pāhoehoe units containing $1-5 \%$ inconspicuous olivine phenocrysts in a light-gray microcrystalline groundmass. Unit is overlain by p2b2 (FID 293). FID 292

Keaīwa Gulch flow-Another tube-fed pāhoehoe found along Ka'ala'ala Gulch in Wood Valley quadrangle. Flow contains $1-5 \%$ olivine phenocrysts and $0-1 \%$ plagioclase in a microcrystalline, gray, feldspathic groundmass. Flow is covered by $0.5-1.5 \mathrm{~m}$ of ash. Unit is overlain by p2b2 (FID 293). FID 294

Flow 340 - Pāhoehoe near highway along Pāhala-Volcano road in Wood Valley quadrangle. Pāhoehoe contains 5-7\% olivine phenocrysts in a light-gray microcrystalline groundmass. Flow surface is orange-stained glassy top. The flow is covered by $0.2-1 \mathrm{~m}$ of ash. Unit is surrounded by p2c6 (FID 301) at the Kīlauea Volcano contact. FID 340

\section{Age Group 3 (2,000-3,000 yr B.P.; Holocene)}

Red Cone flow-' $A$ 'a a flow of Keaīwa Gulch with $0-1 \%$ olivine phenocrysts in a well-crystallized feldspathic groundmass. Prominent flow, north and east of Pāhala town, planted in eucalyptus and macadamia. Unit is locally mantled by ash and is overlain by pāhoehoe flows of Wood Valley (p2f7, FID 289; p2f9, FID 288). Age, 2,072 37 radiocarbon yr B.P. FID 295

Eastern Ka'ōiki Pali flow_Aphanitic ' $a$ 'ā and minor pāhoehoe found on Keauhou Ranch in Kilauea Crater quadrangle. Rock is distinctive in that the groundmass is well crystallized and feldspathic, full of plagioclase microlites. Age, 2,265 \pm 49 radiocarbon yr B.P. FID 889

Nīnole flow-Massive ' $a$ ' $a \bar{a}$ flow at south edge of Pahala quadrangle. Flow forms the northeast edge of Punalu'u Beach. An aphyric 'a'ā has $0-1 \%$ each of olivine and plagioclase phenocrysts. The groundmass is dense, finely crystalline, and feldspathic. Flow has little to no ash cover. Age, 2,365 \pm 30 radiocarbon yr B.P. FID 637

Cow Pasture picrite flow_Pāhoehoe, mostly in north-central Kipuka Pakekake, outliers in northern Wood Valley quadrangle. Flow has a weathered red-orange rind. Rock contains $15-20 \%$ olivine phenocrysts, microphenocrysts. The groundmass is mildly feldspathic. Ash as thick as $0.5 \mathrm{~m}$ overlies this unit. Age, 2,826 32 radiocarbon yr B.P. FID 345 
a315, p315

a3a6

m3a7

a3i8, p3i8, m3i8

p3a9

p3b10

p4a1

p4g2, a4g2

p4a3, a4a3

p4k4

p4I5

p4c6

a4I7

a4j8

a4a9, p4a9

a4a10
Flow 891 - 'A' ā found just southwest of the A.D. 1880 flow. A very distinctive rock that has glomerocrysts of plagioclase and olivine. Contains $9 \%$ plagioclase and $6 \%$ olivine phenocrysts. All these minerals are contrasted against a dark-gray groundmass. Surface color of this flow is tan gray. FID 891

Flow 357-Tiny, composed ( $\sim 1$ acre) of a 5-m-high ' $a$ ‘' . Rock is dense, and the surface lichen covered. Flow is aphyric with sparse angular vesicles. Unit is found in contact with A.D. 1880 flow on the southwest side in central Kipuka Pakekake quadrangle. FID 357

'Alili flow-Mixed 'a'ā and pāhoehoe along the west boundary of Pahala quadrangle. Contains $0-1 \%$ olivine and $0-1 \%$ plagioclase phenocrysts in a light-gray, diktytaxitic groundmass. Flow is blanketed by $0.3-1 \mathrm{~m}$ of ash. FID 554

Flow 884-Dense, weathered 'a'ā and tube-fed pāhoehoe, near the west margin of Kilauea Crater quadrangle. Contains dark-gray groundmass, $2-5 \%$ olivine phenocrysts, and $1-2 \%$ plagioclase as microphenocrysts and rare phenocrysts. Vesicles are subangular to subrounded and may be magnesioferrite lined. Surface is broken and weathered red. FID 884

Ka'ala'ala flow-Pāhoehoe contains $0-1 \%$ olivine in a well-crystallized feldspathic to diktytaxitic groundmass. Found in southwestern Wood Valley quadrangle. Flow is very similar in mineralogy to those surrounding it. The difference being that this unit is buried by $1-3 \mathrm{~m}$ of ash and (or) colluvium. FID 291

Flow 296-Tube-fed pāhoehoe of lower Keaīwa Gulch (northern Pahala quadrangle). Contains $0-3 \%$ olivine phenocrysts. The olivines are light green and sugary in appearance and are small and inconspicuous. The groundmass is well crystallized, feldspathic to diktytaxitic in texture. Flow is mantled by ash. FID 296

$$
\text { Age Group } 4 \text { (3,000-4,000 yr B.P.; Holocene) }
$$

'Ōhaikea flow_Pāhoehoe of 'Ōhaikea (in southwest corner of Kilauea Crater quadrangle). Contains $2-3 \%$ plagioclase microphenocrysts. The plagioclases are fine grained, usually $<0.5 \mathrm{~mm}$. Rare olivine occasionally found. Unit is covered by $10-50 \mathrm{~cm}$ of ash. Age, 3,630 \pm 80 radiocarbon yr B.P. FID 892

Flow 899-Kīpuka in the northeast quadrant of Kipuka Pakekake quadrangle in contact with A.D. 1880 flow. Pāhoehoe contains 3-5\% plagioclase phenocrysts in a well-crystallized light-gray groundmass. Unit is covered with $0.2-0.5 \mathrm{~m}$ of ash. FID 899

Flow 401 - Small kippukas in southwest corner of Kipuka Pakekake quadrangle. Flow is orangeweathered aphanitic pāhoehoe. Contains $0-1 \%$ olivine phenocrysts in well-crystallized lightgray groundmass. Unit here is covered with $0-0.5 \mathrm{~m}$ of ash in low-lying areas. FID 401

Flow 339-Distinctive plagioclase pāhoehoe, in central Wood Valley quadrangle. Contains 5-8\% plagioclase as anhedral snowflake clusters. In addition, unit contains 3-5\% olivine phenocrysts in light-gray, well-crystallized groundmass. FID 339

Wai'akaloa Gulch flow-Distinctive plagioclase-bearing pāhoehoe flow containing 7-10\% olivine as phenocrysts and microphenocrysts and $7-10 \%$ plagioclase as glomeroclasts in a diktytaxitic groundmass. Flow is overlain by ash as thick as $0.3 \mathrm{~m}$. Unit is found in south-central Wood Valley quadrangle. FID 342

Flow 352 - Tan-orange-weathered pāhoehoe in west-central Kipuka Pakekake quadrangle, found as kīpuka in flow p2e8 (FID 346). Flow contains 8\% olivine as very fine laths and phenocrysts in a gray groundmass. In contrast to knobby surface of p2e8 (FID 346), this unit has a smooth surface. Flow mantled by ash. FID 352

Flow 882 - 'A'ā along west boundary of Kilauea Crater quadrangle. Contains $8-12 \%$ olivine phenocrysts, $8-15 \%$ plagioclase phenocrysts, and 5-6\% olivine-plagioclase intergrowths. Plagioclase is more conspicuous than olivine. Unit covered by layers of yellow ash, probably from Kīlauea Volcano, in low-lying areas. FID 882

Flow 890 - Thick 'a'ā west of Ke'āmuku Kīpukakēkake flow in central Kilauea Crater quadrangle. Rock is characterized by $6 \%$ olivine and $1-3 \%$ plagioclase phenocrysts. Groundmass is well crystallized and full of plagioclase microlites. FID 890

Flow 351 - 'A'ā with minor pāhoehoe in northwest corner of Kipuka Pakekake quadrangle. Unit nearly aphanitic yet contains $0.5 \%$ olivine-plagioclase glomeroclasts. Groundmass is medium dark gray. Upper surfaces are orange tan. FID 351

Flow 348 - Aphanitic 'a'ā, east of Napu'ukūlua Lava Flow, in the northwest corner of Kipuka Pakekake quadrangle. Unit is a kīpuka in the younger p3e4 (FID 345). Surface color is 
p4a11, m4a11 Flow 844 - Small pāhoehoe and mixed 'a'à and pāhoehoe kīpuka in the north-central portion of

chocolate gray brown. Abundant ash fills all interstices between (mostly round) clinkers. Contains $0.5 \%$ plagioclase phenocrysts in a medium-light-gray groundmass. Olivine rare, usually intergrown with plagioclase. FID 348

Kipuka Pakekake quadrangle. Units are aphanitic. Pāhoehoe contains $0-1 \%$ olivine phenocrysts in a well-crystallized light-gray groundmass. FID 844

p4a12 Flow 895-Pāhoehoe originates from spatter ramparts uprift of $\mathrm{Pu}^{\text {' }} \mathrm{u}$ 'ula 'ula cone in Kokoolau quadrangle (west of map area). Represents only flows found in Kipuka Pakekake quadrangle. Nearly aphyric, with rare phenocrysts of olivine and plagioclase. Groundmass is medium gray, microcrystalline, and mildly feldspathic with abundant plagioclase microlites. A very large tube system lies within the pāhoehoe. Surface is tan. FID 895

$$
\text { Age Group } 5 \text { (4,000-5,000 yr B.P.; Holocene) }
$$

m5a1 Halfway House flow-Small kippuka in southeastern Kipuka Pakekake and northeastern Wood Valley quadrangles. Unit under $1 \mathrm{~m}$ of ash is a dense aphanitic 'a'ā and pāhoehoe. Groundmass is feldspathic, full of plagioclase microlites. Age, 4,378 \pm 42 radiocarbon yr B.P. FID 399

p5a2, m5a2 Flow 880 - Aphanitic pāhoehoe and dense, fluid, 'a'ā in contact with A.D. 1984 along north boundary of Kipuka Pakekake quadrangle. Flow is characterized by its well-crystallized, medium-gray, feldspathic groundmass. FID 880

'Ahulili flow - Kīpuka in southwest quadrant of Wood Valley quadrangle. 'A'ā contains 5\% olivine phenocrysts in microcrystalline, steely gray groundmass. Unit is blanketed by $2-3 \mathrm{~m}$ of ash. FID 379

p5h4, a5h4 Flow 392 - Kīpuka in north-central Wood Valley and southwestern Kipuka Pakekake quadrangles. A distinctive coarse plagioclase-rich, tube-fed pāhoehoe. Contains variable plagioclase phenocrysts at 10-20\%. Plagioclase comprises aggregates of euhedral plagioclase laths (to $3 \mathrm{~mm}$ ) as glomerocrysts, all in a dark-gray glassy groundmass. Upper surface is orange stained, weathered, glass speckled by coarse plagioclase. Unit is covered by $0-30 \mathrm{~cm}$ of ash. FID 392

p5a5

Ka'ili' ${ }^{6}$ ula flow_Large ash-covered kīpuka upslope of Kapāpala Ranch headquarters in Wood Valley quadrangle. Flow is sparsely olivine-phyric tube-fed pāhoehoe. Contains $0-1 \%$ olivine phenocrysts in light-gray, feldspathic to diktytaxitic groundmass. Unit overlain by $0.5-2 \mathrm{~m}$ of ash. FID 397

Uēwale Gulch flow-Kīpuka in center of Wood Valley quadrangle. Pāhoehoe contains variable amounts of olivine at $5-15 \%$ phenocrysts. Groundmass is a bluish-gray color and cryptocrystalline. Flow differs from other nearby younger regional olivine pāhoehoe by the amount of ash cover, 1-4 m, and its more weathered, eroded upper surface. FID 378

a5b7, p5b7, Kīpukakēkake flow-'A'ā and slabby, tube-fed pāhoehoe in north-central Kilauea Crater $\mathrm{m} 5 \mathrm{~b} 7$ quadrangle. In contact with and isolated by Ke‘āmuku Kīpukakēkake flow (a1g1, FID 800). Rare toothpaste and ' $a$ 'a $\mathrm{a}$ phases exist in southernmost reach of the flow. Contains $0-2 \%$ widely scattered olivine phenocrysts in a gray feldspathic groundmass. Ash cover is nearly continuous. Abundant charcoal samples found where overlain by toes of Ke`āmuku Kīpukakulalio east flow (p1k5, FID 799). FID 870

s5a8

Pu'ukīpū cone - Poorly exposed spatter cone at 4,274-ft elev in northeastern part of Kilauea Crater quadrangle. Spatter is fine grained and aphanitic. FID 871

$$
\text { Age Group 6 (5,000-6,000 yr B.P.; Holocene) }
$$

Flow 988- 'A ' $\bar{a}$ found at distal end and northeast of A.D. 1880 flow. Contains 8-12\% olivine phenocrysts in a medium-gray groundmass. Unit is covered by $0.25 \mathrm{~m}$ of ash. FID 988

a6k2 Kīpukapakēkakē flow-Distinctive plagioclase-bearing 'a'ā contains 5-7\% plagioclase glomerocrysts ("snowflakes") and 3-4\% inconspicuous olivine phenocrysts. Olivine commonly associated with plagioclase. Groundmass medium to dark gray and feldspathic; vesicles are small and well sorted. Unit found in northwestern Kipuka Pakekake quadrangle and southwest of the distal end of A.D. 1880 flow, along the boundary between the Kilauea and Kipuka Pakekake quadrangles. FID 398

a6c3

Flow 990 - Olivine-bearing ' $a$ 'a in northwest quadrant of Kilauea Crater quadrangle along Strip Road. Flow contains $8-10 \%$ sugary anhedral olivine phenocrysts and microphenocrysts. Groundmass is well crystallized and full of plagioclase microlites. Flow is mantled by ash. FID 990

a6a4 Pu'u $\mathbf{4 2 7 4}$ flow-'A'ā in northwest corner of Kilauea Crater quadrangle. This unit is aphanitic. Flow is covered by $1-2 \mathrm{~m}$ ash. FID 986 
Age Group 7 (6,000-7,000 yr B.P.; Holocene)

[No units of this age group are found at the surface in the map area]

Age Group 8 (7,000-8,000 yr B.P.; Holocene)

p8e1

p8b2, a8b2

m8k3, p8k3

a8i4, p8i4

p8e5

p9g2, a9g2

a9k3

p9b4

a9b5, p9b5

p9h1

Halfway House Kīpuka flow-Pāhoehoe located in southeast corner of Kipuka Pakekake and northeastern Wood Valley quadrangles, with distinctive snowflakes or rosettes of plagioclase. Contains $18-20 \%$ euhedral blades intergrown to form glomeroclasts of plagioclase. Unit also contains minor olivine. Flow is covered by 0.5 to $1.5 \mathrm{~m}$ of ash. Age, 8,520 182 radiocarbon yr B.P. FID 395

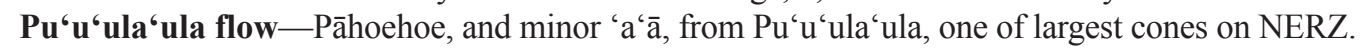
Located in central part of Kilauea Crater quadrangle. Distinct unit, containing 3-4\% fine plagioclase phenocrysts. Flow groundmass is light gray and orange stained, with many inconspicuous needles of plagioclase. Flow is commonly covered with as much as $1 \mathrm{~m}$ of tan ash, especially at lower elevations; outcrops are fairly common. Age, 8,645 71 radiocarbon yr B.P. FID 978

Flow 402-'A'ā in northwest corner of Wood Valley quadrangle. Contains 8-10\% anhedral plagioclase glomeroclasts and laths in a well-crystallized groundmass. Flow has $1 \%$ olivine phenocrysts. Upper surfaces are orange stained. Unit is covered by $0.5 \mathrm{~m}$ of ash. FID 402

Flow 393 - Tube-fed pāhoehoe found in northwest quadrant of Wood Valley and southeast corner of Kipuka Pakekake quadrangles. Unit has orange, weathered, glassy rind top and is characteristically overlain by $1 \mathrm{~m}$ of ash. Contains $5 \%$ olivine as inconspicuous anhedral phenocrysts and rare laths. FID 393

Flow 944 - Old 'a'ā and tube-fed pāhoehoe, yellow stained and exposed only in gullies. Contains $1-2 \%$ anhedral olivine phenocrysts in a well-crystallized groundmass. Upper surfaces are orange stained. Flow is covered by $0.2-1 \mathrm{~m}$ of ash. Unit forms small kīpuka within largest p9g2 (FID 978) unit near Kīlauea Volcano contact in central Kilauea Crater quadrangle. FID 944

$$
\text { Age Group } 10 \text { (9,000-10,000 yr B.P.; Holocene) }
$$

m10b1, p10b1， Ka'ū High School flow-Tube-fed pāhoehoe that underlies the town of Pāhala. Contains 0-5\% a10b1 olivine phenocrysts in a well-crystallized groundmass. Flow tops are stained orange red. Flow is buried by $1.5-2 \mathrm{~m}$ of ash. Age, 9,121 446 radiocarbon yr B.P. FID 383 
p10c2 Lae`opuhili flow_Large regional pāhoehoe in Pahala quadrangle. Pāhoehoe contains 7-10\% olivine phenocrysts in light-gray diktytaxitic groundmass. Unit is covered by 0.3 to $1 \mathrm{~m}$ of ash. Age, 9,218 79 radiocarbon yr B.P. FID 742

p10a3 Flow 338 - Abandoned cane fields, ash covered, below Kapāpala Ranch Headquarters in southern Wood Valley quadrangle. Flow buried by $0.5-1.2 \mathrm{~m}$ of ash. Pāhoehoe has $0-1 \%$ olivine phenocrysts and microphenocrysts in a dull light-gray microcrystalline groundmass. Age, 9,680 70 radiocarbon yr B.P. FID 338

m10k4, p10k4, 'Iliokōloa flow_Flow in Pahala quadrangle. Unit has both 'a'ā and pāhoehoe phases, informally a10k4 known as the "plagioclase-rich flow" of Pahala quadrangle. Plagioclase ranges from $3-8 \%$ as anhedral clots and laths. Also contains $1-8 \%$ olivine as green phenocrysts and microphenocrysts. Unit is overlain by 0.5 to $5 \mathrm{~m}$ of ash. FID 382

a10i5 Flow 943 — Small ash-covered 'a'ā kīpuka in southwestern part of Kilauea Crater quadrangle; surrounded by ash (ts) unit. Contains $5 \%$ plagioclase and $3 \%$ sugary olivine phenocrysts in a dense microcrystalline groundmass. Unit is covered by $2.5 \mathrm{~m}$ of ash. FID 943

p10g6 Flow 942 — Small ash-covered pāhoehoe kīpuka in southwestern part of Kilauea Crater quadrangle, surrounded by ash (ts) unit. Contains $4-5 \%$ plagioclase in a dense microcrystalline groundmass. Unit is covered by $1.0-2.5 \mathrm{~m}$ of ash. FID 942

$$
\text { Age Group } 11 \text { (10,000-15,000 yr B.P.; Holocene and Pleistocene) }
$$

p11a1

a11a2, p11a2

Kauhuhu'ula flow - Aphyric pāhoehoe of Kauhuhu'ula Gulch, Pahala quadrangle. Contains rare olivine phenocrysts. The groundmass is full of plagioclase microlites. Surface color of flow is yellow orange. Unit is buried by $1.5 \mathrm{~m}$ of ash. Ka' $\bar{u}$ High School flow (m10b1, FID 383) overlies this unit. FID 390

$\mathbf{P} \overline{\mathbf{a}}^{\prime} \mathbf{a} \mathbf{a} \mathbf{u}^{\prime} \mathbf{a u}$ flow-Mixed 'a'ā and pāhoehoe of $\mathrm{P} \overline{\mathrm{a}}$ 'au'au Gulch in central Pahala quadrangle. Contains $0-1 \%$ olivine phenocrysts and microphenocrysts. Groundmass is dense and microcrystalline. Unit is buried by $1.0 \mathrm{~m}$ of ash. Age, 10,030 185 radiocarbon yr B.P. FID 388

p11b3 Meyer Camp flow-Very vesicular pāhoehoe with near-vent-type vesicularity in central Pahala quadrangle. Outcrop appears to be large tube system and (or) channel overbank deposit. Contains $2-3 \%$ olivine phenocrysts in microcrystalline gray groundmass. Unit is buried by $1-2 \mathrm{~m}$ of ash. Age, 10,600 \pm 150 radiocarbon yr B.P. FID 386

a11a4 Wailoa flow_Aphyric 'a'ā northeast of Pāhala town. Unit contains rare olivine phenocrysts. Groundmass is full of plagioclase microlites. Surface color of flow is yellow orange. Flow is buried by $1.5 \mathrm{~m}$ of ash. Ka' $\bar{u}$ High School flow (m10b1, FID 383) overlies this unit. FID 391

Age Group 12 (15,000-20,000 yr B.P.; Pleistocene)

[No units of this age group are found at the surface in the map area]

Age Group 13 (20,000-30,000 yr B.P.; Pleistocene)

m13b1

a13b2

a13f3, p13f3

Flow 387-Mixed 'a'ā and pāhoehoe above town of Pāhala occurs as two kīpuka within Ka' $\bar{u}$ High School flow (m10b1, FID 383). Unit contains 0-3\% olivine phenocrysts in a well-crystallized groundmass. Flow tops are stained orange red. Unit is buried by $1.5-2 \mathrm{~m}$ of ash. FID 387

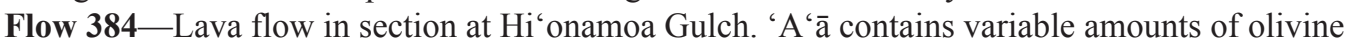
phenocrysts from $1-7 \%$ in a microcrystalline bluish-gray groundmass. Flow is under $\mathrm{Ka}$ ' $\bar{u}$ High School flow (m10b1, FID 383). Unit is covered by $0.5-1.0 \mathrm{~m}$ of ash. Age, $25,768 \pm 188$ radiocarbon yr B.P. FID 384

Lava flow of Hi'onamoa Gulch — 'A' $\mathrm{a}$ and pāhoehoe lining the floor of Hi'onamoa and Moa'ula Gulches near Highway 11 in Pahala quadrangle. Contains variable amounts of olivine, ranging from $0-8 \%$ as phenocrysts in a microcrystalline bluish-gray groundmass. Flow is overlain by the Ka' $\bar{u}$ High School flow (m10b1, FID 383). Unit is covered by $0.5-1.0 \mathrm{~m}$ of ash. Age, $28,140 \pm 590$ radiocarbon yr B.P. FID 735

\section{Kahuku Basalt}

The Kahuku Basalt consists of units with an age range of 30,000 to 100,000 yr. The Kahuku Basalt is composed of tholeiitic basalt, tuffs, vent deposits, and lava flows that rest unconformably on the Ninole Basalt. The flows are mostly aphyric and some have variable amounts of olivine and plagioclase phenocrysts. The Kahuku Basalt type locality is the Kahuku Pali or Kahuku Fault near Kalae (South Point). 
Age Group 14 (30,000-100,000 yr B.P.; Pleistocene)

[No units of this age group are found at the surface in the map area]

Nīnole Basalt

The Ninnole Basalt, the oldest exposed rocks on Mauna Loa, is $>100,000 \mathrm{yr}$ B.P. These rocks are exposed in the Ka'u $\bar{u}$ District. The Nīnole Basalt consists of tholeiitic basalt, tuffs, vent deposits, and lava flows. The flows are mostly aphyric and some have variable amounts of olivine and plagioclase phenocrysts.

$$
\text { Age Group } 15 \text { (>100,000 yr B.P.; Pleistocene) }
$$

$\mathrm{n}$

Nīnole Basalt-Undivided units found in valley wall of Wood Valley. Flows are mostly aphyric and deeply weathered and have variable amounts of olivine and plagioclase phenocrysts. Lipman and others (1990) report a weighted mean age of $0.120 \pm 0.056 \mathrm{Ma}$ for Nīnole Basalt. Whereas, Jicha and others (2012) constrain the Ninole Basalts to have erupted from 0.227 to $0.108 \mathrm{Ma}$. FID 744

\section{DISTAL TEPHRA DEPOSITS}

\section{Tephra (Holocene and Pleistocene)}

Southern tephra-Beds of ashfall deposits in map area are chiefly from Kīlauea Volcano and likely include contributions from Mauna Loa (Easton, 1987). All ash deposits $\leq 10,000 \mathrm{yr}$ B.P. are included in this category. Kîlauea deposits include ${ }^{14} \mathrm{C}$ ages of $2,110 \pm 120 \mathrm{yr}$ B.P., $2,265 \pm 50$ yr B.P., and 2,770 \pm 70 yr B.P., all dating Uwēkahuna Ash Member of Puna Basalt

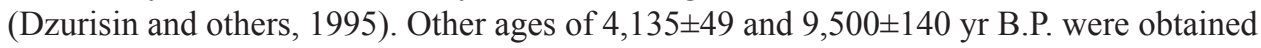
from ash layers on the east flank of the volcano. Distributions of ash near Kîlauea seem to be influenced by the inversion layer on the windward coast of the Island of Hawai' $i$. This meteoric phenomenon appears to limit distribution of ash to lower elevations; therefore, overlay patterns for ash deposits may vary with elevation within flows or on flows of similar age. Possibly, ash deposited at higher elevations (alpine and above) lack vegetative cover that preserves it, allowing combined wind and rainfall to strip ash deposits from higher elevations. FID 959

Pāhala Ash—Deep Pāhala Ash 5-8 m thick exposed at the surface. Unit comprises several kipukas in northwest-central Pahala quadrangle. Unit is older than surficial ash deposits (ts; FID 959). Unit comprises multiply bedded airfall deposits whose origin is unknown. Most likely, Pāhala Ash has Kīlauea Volcano origin, although Mauna Loa cannot be excluded as a source. Unit is overlain by flows p11a1 (FID 390) and p11a2 (FID 388), dated at 12,500 and 10,030 radiocarbon yr B.P., respectively. Age, 31,020 310 radiocarbon yr B.P. FID 389 


\section{Selected References}

Buchanan-Banks, J.M., 1993, Geologic map of Hilo 7 1/2' quadrangle, Island of Hawaii: U.S. Geological Survey Miscellaneous Investigations Series Map I-2274, scale $1: 24,000,17 \mathrm{p}$.

Buchanan-Banks, J.M., Lockwood, J.P., and Rubin, Meyer, 1989, Radiocarbon dates for lava flows from Northeast Rift Zone of Mauna Loa volcano, Hilo 7 1/2' quadrangle, Island of Hawaii: Radiocarbon, v. 31, no. 2, p. 179-186.

Dzurisin, D., Lockwood, J.P., Casadevall, T.J., and Rubin, Meyer, 1995, The Uwekahuna Ash Member of the Puna Basalt_-Product of violent phreatomagmatic eruptions at Kîlauea Volcano, Hawai'i, between 2,800 and 2,100 ${ }^{14} \mathrm{C}$ years ago: Journal of Volcanology and Geothermal Research, v. 66, no. 1-4, p. 163-184.

Easton, M., 1987, Stratigraphy of Kilauea Volcano, in Decker, R.W., Wright, T.L., and Stauffer, P.H., eds., Volcanism in Hawaii: U.S. Geological Survey Professional Paper 1350, v. 1 , chap. 11 , p. 243-260.

Finch, R.H., and Macdonald, G.A., 1953, Hawaiian volcanoes during 1950: U.S. Geological Survey Bulletin 996-B, p. 27-89.

Fraser, G.D., 1960, Pahala ash-An unusual deposit from Kilauea Volcano, Hawaii: U.S. Geological Survey Professional Paper 400-B, p. 354-355.

Jackson, M.D., Endo, E.T., Delaney, P.T., Arnadottir, T., and Rubin. A.M., 1992, Ground ruptures of the 1974 and Kaoiki earthquakes, Mauna Loa, Hawaii: Journal of Geophysical Research, v. 97, no. B6, p. 8775-8796.

Jicha, B.R., Rhodes, J.M., Singer, B.S., and Garcia, M.O., $2012,{ }^{40} \mathrm{Ar} /{ }^{39} \mathrm{Ar}$ geochronology of submarine Mauna Loa volcano, Hawaii: Journal of Geophysical Research B, Solid Earth, v. 117, no. 9, 10.1029/2012JB009373, B09204.

Kelley, M.L., 1979, Radiocarbon dates from the Hawaiian Islands-A compilation: U.S. Geological Survey OpenFile Report 79-1700, 37 p.

Kelley, M.L., Spiker, E.C., Lipman, P.W., Lockwood, J.P., Holcomb, R.T., and Rubin, Meyer, 1979, U.S. Geological Survey, Reston, Virginia, Radiocarbon Dates XV-Mauna Loa and Kilauea volcanoes, Hawaii: Radiocarbon, v. 21, no. 2, p. 306-320.

Lipman, P.W., 1980, Rates of volcanic activity along the southwest rift zone of Mauna Loa Volcano, Hawaii: Bulletin Volcanologique, v. 43, no. 4, p. 703-725.

Lipman, P.W., and Swenson, A., 1984, Generalized geologic map of the southwest rift zone of Mauna Loa volcano, Hawaii: U.S. Geological Survey Miscellaneous Investigations Series Map I-1323, scale 1:100,000.

Lipman, P.W., Rhodes, J.M., and Dalrymple, G.B., 1990, The Ninole Basalt - Implications for the structural evolution of Mauna Loa volcano, Hawaii: Bulletin of Volcanology, v. 53, p. 1-19.
Lockwood, J.P., 1995, Mauna Loa eruptive history-The preliminary radiocarbon record, in Rhodes, J.M., and Lockwood, J.P., eds., Mauna Loa revealed-Structure, composition, history, and hazards: American Geophysical Union Geophysical Monograph 92, p. 81-94.

Lockwood, J.P., Banks, N.G., English, T.T., Greenland, L.P., Jackson, D.B., Johnson, D.J., Koyanagi, R.Y., McGee, R.A., Okamura, A.T., and Rhodes, J.M., 1985, The 1984 eruption of Mauna Loa Volcano, Hawaii: Eos, Transactions, American Geophysical Union, v. 66, no. 16, p. 169-171.

Lockwood, J.P., and Lipman, P.W., 1980, Recovery of datable charcoal from beneath young lava flows-Lessons from Hawaii: Bulletin Volcanologique, v. 43, no. 3, p. 609-615.

Lockwood, J.P., and Lipman, P.W., 1987, Holocene eruptive history of Mauna Loa volcano, in Decker, R.W., Wright, T.L., and Stauffer, P.H., eds., Volcanism in Hawaii: U.S. Geological Survey Professional Paper 1350, v. 1, chap. 18, p. 509-536.

Rubin, Meyer, Gargulinski, L.K., and McGeehin, J.P., 1987, Hawaiian radiocarbon dates, in Decker, R.W., Wright, T.L., and Stauffer, P.H., eds., 1987, Volcanism in Hawaii: U.S. Geological Survey Professional Paper 1350, v. 1, chap. 10, p. 213-242.

Stearns, H.T., and Clark, W.O., 1930, Geology and water resources of the Kau District, Hawaii: U.S. Geological Survey Water-Supply Paper 616, 194 p.

Stearns, H.T., and Macdonald, G.A., 1946, Geology and ground-water resources of the island of Hawaii: Hawaii (Territory) Division of Hydrography Bulletin 9, scale $1: 125,000,363 \mathrm{p}$.

Stone, J.B., 1926, The products and structure of Kilauea: Bernice P. Bishop Museum, Bulletin 33, 59 p., includes plates.

Stuiver, Minze, Reimer, P.J., Bard, Edouard, Beck, J.W., Burr, G.S., Hughen, K.A., Kramer, Bernd, McCormac, Gerry, van der Plicht, Johannes, and Spurk, Marco, 1998, INTCAL98 radiocarbon age calibration, 24,000-0 cal BP: Radiocarbon, v. 40, no. 3, p. 1041-1083.

Stuiver, M., Reimer, P.J., and Reimer, R.W. 2005, CALIB Radiocarbon Calibration: Marine Reservoir Correction Database (program and documentation), v. 6.0, http:// calib.org/calib/.

Taylor, J.R., 1982, An introduction to error analysis: Mill Valley, Calif., University Science Books, 270 p.

Trusdell, F.A., 1995, Lava flow hazards and risk assessment on Mauna Loa Volcano, Hawaii, in Rhodes, J.M., and Lockwood, J.P., eds., Mauna Loa revealed-Structure, composition, history, and hazards: American Geophysical Union, Monograph 92, p. 327-336.

Walker, G.W., 1969, Geologic map of the Kau Desert quadrangle, Hawaii: U.S. Geological Survey Geologic Quadrangle Map GQ-827.

Wentworth, C.K., 1938, Ash formation of the Island of Hawaii: Honolulu, Hawaiian Volcano Observatory of Hawaii 
National Park and Hawaiian Volcano Research Association, 3rd special report, $183 \mathrm{p}$.

Wolfe, E.W., and Morris, Jean, 1996a, Geologic Map of the Island of Hawaii: U.S. Geological Survey Miscellaneous Investigations Series Map I-2524-A, scale 1:100,000, $18 \mathrm{p}$.

Wolfe, E.W., and Morris, Jean, 1996b, Sample data for the geologic map of the Island of Hawaii: U.S. Geological Survey Miscellaneous Investigations Series Map I-2524-B, scale $1: 100,000,51 \mathrm{p}$

\section{Hawaiian Language References}

Pukui, M.K., Elbert, S.H., and Mookini, E.T., 1974, Place names of Hawaii: Honolulu, University of Hawaii Press, 289 p.

United States Board on Geographic Names, 2018, Geographic names database: U.S. Geological Survey, https://geonames. usgs.gov/.

University of Hawaii Geography Department, 1974, Atlas of Hawaii: Honolulu, University of Hawaii Press, 250 p.

\section{Appendix}

This appendix contains radiocarbon ages that were rejected and not used in the study of the central-southeast flank of Mauna Loa volcano, Island of Hawai'i, Hawaii. Reasons for being rejected include age too old or too young, age not consistent with stratigraphy, and sample contaminated.

\begin{tabular}{|c|c|c|c|c|c|c|}
\hline FID $^{1}$ & Field No. & Lab No. & $\begin{array}{c}\text { Quadrangle name } \\
(1: 24,000)\end{array}$ & $\begin{array}{c}\text { Age }^{2} \\
\text { (yr B.P.) }\end{array}$ & $\begin{array}{l}\text { S.D. } \\
(\mathrm{yr})\end{array}$ & Data source $^{3}$ \\
\hline 289 & 9P74C & W5325 & Pahala & 1,370 & 200 & 1 \\
\hline 289 & L-01-501c & WW3711 & Wood Valley & 1,560 & 35 & 1 \\
\hline 289 & L-90-81 & W6456 & Wood Valley & 1,820 & 80 & 1 \\
\hline 289 & L-91-143 & W6460 & Keaiwa Reservoir & 1,850 & 80 & 1 \\
\hline 289 & L-91-191 & W6462 & Wood Valley & 1,920 & 80 & 1 \\
\hline 344 & L-81-67 & W5083 & Mauna Loa & 1,030 & 60 & 1 \\
\hline 799 & L-77-42A & W3879 & Kilauea Crater & 830 & 60 & 1 \\
\hline 799 & KUc-130 & W4870 & Kulani & 1,100 & 70 & 2 \\
\hline 801 & 77L-09 & W3836 & Kilauea Crater & 2,830 & 60 & 2 \\
\hline 801 & L-80-126 & W4801 & Kilauea Crater & 730 & 70 & 2 \\
\hline 838 & L-78-1 & W4049 & Kipuka Pakekake & 420 & 70 & 2 \\
\hline 838 & PUd-135 & W4571 & Puu Ulaula & 440 & 70 & 2 \\
\hline 892 & 77L-08 & W3855 & Kilauea Crater & 4,210 & 200 & 1 \\
\hline
\end{tabular}


Table 2. Radiocarbon ages of samples from the central-southeast flank of Mauna Loa volcano, Island of Hawai'i, Hawaii.

[All ages are reported in radiocarbon years before present (yr B.P., before the calendar year datum of A.D. 1950). Materials dated include charcoal, roots, twigs, vegetative litter, or unaltered wood (rarely). See figure 1 for quadrangle locations]

\begin{tabular}{|c|c|c|c|c|c|c|}
\hline Unit label $^{1}$ & FID $^{2}$ & $\begin{array}{c}\text { Age }^{1} \\
\text { group }\end{array}$ & Unit name & Field No. & Lab No. ${ }^{3}$ & $\begin{array}{c}\text { Quadrangle name } \\
(1: 24,000)\end{array}$ \\
\hline a1g1 & 800 & 1 & Ke`āmuku Kīpukakēkake flow & $77 \mathrm{~L}-24 \mathrm{~A}$ & W3871 & Kilauea Crater \\
\hline a1g1 & 800 & 1 & Ke‘āmuku Kīpukakēkake flow & L-78-26 & W4360 & Kilauea Crater \\
\hline a1g1 & 800 & 1 & Ke‘āmuku Kīpukakēkake flow & 77L-24B & W4919 & Kilauea Crater \\
\hline p1k2 & 801 & 1 & Kīpukamauna'iu flow & 77L-06 & W3843 & Kilauea Crater \\
\hline p1k2 & 801 & 1 & Kīpukamauna'iu flow & 77L-29 & W4006 & Kilauea Crater \\
\hline p1k2 & 801 & 1 & Kīpukamauna'iu flow & L-78-14 & W4183 & Kipuka Pakekake \\
\hline p1k2 & 801 & 1 & Kīpukamauna'iu flow & L-82-01 & W5106 & Kilauea Crater \\
\hline p1k2 & 801 & 1 & Kīpukamauna'iu flow & F01-37-01c & WW3541 & Kilauea Crater \\
\hline p1a3 & 274 & 1 & Ke A Po'omoku Flow & L-80-100 & W4790 & Kipuka Pakekake \\
\hline p1a3 & 274 & 1 & Ke A Po‘omoku Flow & L-80-165 & W4805 & Kilauea Crater \\
\hline p1a3 & 274 & 1 & Ke A Po'omoku Flow & L-87-07 & W6001 & Kipuka Pakekake \\
\hline p1g4 & 802 & 1 & Ke‘āmuku Kīpukakulalio flow & L-78-04 & W4118 & Puu Ulaula \\
\hline p1g4 & 802 & 1 & Ke‘āmuku Kīpukakulalio flow & $\mathrm{L}-78-04 \mathrm{R}^{10}$ & W4916 & Puu Ulaula \\
\hline a1k5 & 799 & 1 & Ke‘āmuku Kīpukakulalio east flow & L-77-42B & W3880 & Kilauea Crater \\
\hline a1k5 & 799 & 1 & Ke‘āmuku Kīpukakulalio east flow & MP-78-07 & W4367 & Kilauea Crater \\
\hline a1k5 & 799 & 1 & Ke‘āmuku Kīpukakulalio east flow & L-80-24 & W4845 & Kilauea Crater \\
\hline $\mathrm{p} 116$ & 833 & 1 & Keauhou Ranch flow & L-78-27 & W4345 & Kilauea Crater \\
\hline a1b7 & 840 & 1 & Flow northeast of 1880 lobe & L-80-90 & W4863 & Kipuka Pakekake \\
\hline p1e8 & 837 & 1 & $\mathrm{Pu}$ 'uwahi picrite flow & $\mathrm{L}-77-45$ & W4047 & Kipuka Pakekake \\
\hline p1e8 & 837 & 1 & Pu'uwahi picrite flow & $\mathrm{L}-77-45 \mathrm{R}$ & SUERC-5409 & Kipuka Pakekake \\
\hline p2b2 & 293 & 2 & West Wood Valley flow & $9 \mathrm{WV} 2 \mathrm{C}$ & W4430 & Wood Valley \\
\hline p2b2 & 293 & 2 & West Wood Valley flow & MJ-87-C5 & W6037 & Pahala \\
\hline p2i3 & 298 & 2 & Pahuamimi flow & L-93-119 & USGS3466 & Kipuka Pakekake \\
\hline p2i3 & 298 & 2 & Pahuamimi flow & KP-01 & W3000 & Wood Valley \\
\hline p2i3 & 298 & 2 & Pahuamimi flow & MJ-87-C2 & W6014 & Kipuka Pakekake \\
\hline p2a4 & 297 & 2 & Keakapulu Flat flow & MJ-87-C3 & W6012 & Wood Valley \\
\hline p2a4 & 297 & 2 & Keakapulu Flat flow & L-92-159 & USGS3461 & Wood Valley \\
\hline p2i5 & 344 & 2 & Kapāpala flow & MJ-87-C4 & W5982 & Wood Valley \\
\hline p2i5 & 344 & 2 & Kapāpala flow & L-92-181 & WW323 & Wood Valley \\
\hline p2i5 & 344 & 2 & Kapāpala flow & L-92-212 & USGS3462 & Kipuka Pakekake \\
\hline p2c6 & 301 & 2 & Kilohana flow & L-91-588 ${ }^{10}$ & WW319 & Keaiwa Reservoir \\
\hline p2c6 & 301 & 2 & Kilohana flow & L-92-654 & USGS3474 & Wood Valley \\
\hline p2c6 & 301 & 2 & Kilohana flow & MJ-87-C1 & W5679 & Wood Valley \\
\hline p2f7 & 289 & 2 & Waimuku flow & L-84-06c & W5461 & Wood Valley \\
\hline p2f7 & 289 & 2 & Waimuku flow & 77L-63 & W4359 & Pahala \\
\hline p2f7 & 289 & 2 & Waimuku flow & L-01-501c & WW3711 & Wood Valley \\
\hline p2f7 & 289 & 2 & Waimuku flow & 77L-17A & W3857 & Pahala \\
\hline p2f7 & 289 & 2 & Waimuku flow & 77L-17B & W3858 & Pahala \\
\hline p2e8 & 346 & 2 & $\mathrm{Pu}^{\prime} \mathrm{u}^{\prime}$ ele'ele flow & L-92-129 & WW846 & Wood Valley \\
\hline p2e8 & 346 & 2 & $\mathrm{Pu}^{6} \mathrm{u}^{6}$ ele'ele flow & L-93-242 & WW852 & Kipuka Pakekake \\
\hline p2f9 & 288 & 2 & Ka'ala'ala Gulch flow & L-92-2014 & SUERC10374 & Pahala \\
\hline p2f9 & 288 & 2 & Ka'ala'ala Gulch flow & L-92-507D & SUERC10382 & Pahala \\
\hline p2b10 & 290 & 2 & Kapāpala Ranch flow & L-91-602 $2^{10}$ & USGS3468 & Keaiwa Reservoir \\
\hline p2b10 & 290 & 2 & Kapāpala Ranch flow & L-99-553 & WW2626 & Wood Valley \\
\hline
\end{tabular}




\begin{tabular}{|c|c|c|c|c|c|c|c|c|c|}
\hline $\begin{array}{l}\text { Latitude }^{4} \\
\text { (degree) }\end{array}$ & $\begin{array}{c}\text { Longitude }^{4} \\
\text { (degree) }\end{array}$ & $\begin{array}{l}\text { Elev } \\
\text { (ft) }\end{array}$ & $\begin{array}{c}\text { Age }^{5} \\
\text { (yr B.P.) }\end{array}$ & $\begin{array}{l}\text { S.D. } \\
(y r)\end{array}$ & $\begin{array}{c}\text { Weighted average } \\
\text { (yr B.P.) }\end{array}$ & $\begin{array}{l}\text { S.D. }^{6} \\
(\mathrm{yr})\end{array}$ & Quality $^{7}$ & $\begin{array}{c}\text { Age range } \\
\text { (calendar years) }\end{array}$ & Source $^{9}$ \\
\hline 19.44321 & -155.31630 & 4,200 & 230 & 60 & 288 & 36 & + & 1491 to 1953 & 1,2 \\
\hline 19.49084 & -155.34227 & 5,500 & 300 & 60 & 288 & 36 & + & 1448 to 1951 & 2 \\
\hline 19.44324 & -155.31627 & 4,203 & 350 & 70 & 288 & 36 & 0 & 1433 to 1790 & 2 \\
\hline 19.40565 & -155.34085 & 3,500 & 290 & 50 & 311 & 25 & - & 1460 to 1950 & 1,2 \\
\hline 19.40897 & -155.33940 & 3,590 & 290 & 70 & 311 & 25 & 0 & 1447 to 1951 & 1,2 \\
\hline 19.49261 & -155.44146 & 8,360 & 300 & 60 & 311 & 25 & + & 1448 to 1951 & 1,2 \\
\hline 19.41252 & -155.34698 & 3,825 & 300 & 80 & 311 & 25 & + & 1437 to 1952 & 2 \\
\hline 19.41124 & -155.34172 & 3,570 & 340 & 40 & 311 & 25 & - & 1462 to 1642 & 3 \\
\hline 19.43715 & -155.39977 & 5,280 & 540 & 70 & 475 & 41 & + & 1285 to 1464 & 2 \\
\hline 19.39405 & -155.36860 & 3,790 & 340 & 60 & 475 & 41 & 0 & 1445 to 1653 & 2 \\
\hline 19.40651 & -155.38265 & 4,350 & 720 & 100 & 475 & 41 & 0 & 1048 to 1422 & 3 \\
\hline 19.50088 & -155.38320 & 6,815 & 580 & 80 & 569 & 53 & + & 1274 to 1449 & 1,2 \\
\hline 19.50088 & -155.38320 & 6,815 & 560 & 70 & 569 & 53 & + & 1287 to 1446 & 3 \\
\hline 19.45195 & -155.28359 & 4,100 & 530 & 60 & 575 & 38 & + & 1296 to 1453 & 1,2 \\
\hline 19.44277 & -155.27337 & 4,060 & 570 & 70 & 575 & 38 & + & 1286 to 1442 & 2 \\
\hline 19.46805 & -155.29302 & 4,425 & 640 & 70 & 575 & 38 & 0 & 1262 to 1424 & 2 \\
\hline 19.48993 & -155.34121 & 5,450 & 760 & 70 & - & - & + & 1050 to 1392 & 2 \\
\hline 19.48373 & -155.41635 & 7,395 & 780 & 70 & - & - & + & 1045 to 1387 & 2 \\
\hline 19.48408 & -155.38352 & 6,350 & 910 & 70 & 955 & 24 & + & 1016 to 1259 & 1,2 \\
\hline 19.48408 & -155.38353 & 6,350 & 961 & 25 & 955 & 24 & + & 1020 to 1155 & 3 \\
\hline 19.26468 & -155.48276 & 2,260 & 1,270 & 70 & 1,281 & 66 & + & 645 to 940 & 2 \\
\hline 19.22045 & -155.46248 & 1,180 & 1,290 & 120 & 1,281 & 66 & + & 543 to 994 & 3 \\
\hline 19.38563 & -155.38252 & 3,720 & 1,285 & 30 & 1,293 & 27 & + & 662 to 777 & 3 \\
\hline 19.37141 & -155.37367 & 3,000 & 1,330 & 70 & 1,293 & 27 & + & 597 to 876 & 1 \\
\hline 19.37390 & -155.37478 & 3,380 & 1,310 & 120 & 1,293 & 27 & + & 467 to 992 & 3 \\
\hline 19.37075 & -155.39729 & 3,680 & 1,360 & 120 & 1,428 & 38 & + & 428 to 948 & 3 \\
\hline 19.33970 & -155.42802 & 3,190 & 1,435 & 40 & 1,428 & 38 & + & 556 to 660 & 3 \\
\hline 19.35599 & -155.45361 & 4,280 & 1,460 & 100 & 1,469 & 32 & + & 386 to 775 & 3 \\
\hline 19.33889 & -155.45235 & 3,675 & 1,480 & 60 & 1,469 & 32 & + & 433 to 656 & 3 \\
\hline 19.37196 & -155.49370 & 6,180 & 1,465 & 40 & 1,469 & 32 & + & 475 to 657 & 3 \\
\hline 19.36258 & -155.50893 & 6,600 & 1,560 & 70 & 1,507 & 19 & + & 349 to 641 & 3 \\
\hline 19.31153 & -155.46132 & 3,250 & 1,505 & 20 & 1,507 & 19 & + & 470 to 614 & 3 \\
\hline 19.28646 & -155.43131 & 2,200 & 1,360 & 150 & 1,507 & 19 & 0 & 393 to 993 & 3 \\
\hline 19.28060 & -155.49265 & 3,160 & 1,510 & 110 & 1,511 & 24 & + & 258 to 765 & - \\
\hline 19.22904 & -155.45683 & 1,305 & 1,510 & 60 & 1,511 & 24 & + & 427 to 644 & - \\
\hline 19.26165 & -155.46675 & 1,930 & 1,560 & 34 & 1,511 & 24 & + & 420 to 572 & - \\
\hline 19.22046 & -155.46249 & 1,190 & 1,470 & 60 & 1,511 & 24 & 0 & 433 to 661 & 1,2 \\
\hline 19.22046 & -155.46249 & 1,190 & 1,400 & 60 & 1,511 & 24 & 0 & 541 to 770 & 1,2 \\
\hline 19.35027 & -155.39015 & 2,875 & 1,550 & 50 & 1,530 & 37 & + & 409 to 636 & 3 \\
\hline 19.43314 & -155.45902 & 7,060 & 1,510 & 50 & 1,530 & 37 & + & 427 to 649 & 3 \\
\hline 19.23651 & -155.47197 & 1,190 & 1,561 & 35 & 1,574 & 25 & + & 419 to 573 & - \\
\hline 19.23551 & -155.47158 & 1,518 & 1,586 & 35 & 1,574 & 25 & + & 406 to 533 & - \\
\hline 19.32433 & -155.52688 & 6,290 & 1,500 & 30 & 1,622 & 23 & + & 442 to 638 & 3 \\
\hline 19.29682 & -155.45998 & 2,940 & 1,585 & 60 & 1,622 & 23 & - & 341 to 603 & 3 \\
\hline
\end{tabular}


Table 2. Radiocarbon ages of samples from the central-southeast flank of Mauna Loa volcano, Island of Hawai $i$, Hawaii.-Continued [All ages are reported in radiocarbon years before present (yr B.P., before the calendar year datum of A.D. 1950). Materials dated include charcoal, roots, twigs, vegetative litter, or unaltered wood (rarely). See figure 1 for quadrangle locations]

\begin{tabular}{|c|c|c|c|c|c|c|}
\hline Unit label $^{1}$ & FID $^{2}$ & $\begin{array}{c}\text { Age }^{1} \\
\text { group }\end{array}$ & Unit name & Field No. & Lab No. ${ }^{3}$ & $\begin{array}{c}\text { Quadrangle name } \\
(1: 24,000)\end{array}$ \\
\hline p2b10 & 290 & 2 & Kapāpala Ranch flow & $\mathrm{L}-91-625^{10}$ & W6480 & Keaiwa Reservoir \\
\hline a2k11 & 864 & 2 & Upper Waiākea flow & HCB-83-15 10 & W5278 & Hilo \\
\hline a2k11 & 864 & 2 & Upper Waiākea flow & L-92-237 10 & USGS3463 & Piihonua \\
\hline $\mathrm{a} 2 \mathrm{k} 11$ & 864 & 2 & Upper Waiākea flow & KUc- $101^{10}$ & W4344 & Kulani \\
\hline a2k11 & 864 & 2 & Upper Waiākea flow & GAM- $01^{10}$ & W477 & Piihonua \\
\hline a2k11 & 864 & 2 & Upper Waiākea flow & GAM- $02^{10}$ & W478 & Piihonua \\
\hline p2e14 & 343 & 2 & Kauhiuhi flow & L-84-02 & W5458 & Wood Valley \\
\hline p2b15 & 336 & 2 & East Wood Valley flow & 2WV1C & W5271 & Wood Valley \\
\hline p2b15 & 336 & 2 & East Wood Valley flow & L-90-81 & W6456 & Wood Valley \\
\hline p2b16 & 540 & 2 & Moa'ula flow & 77L-04 & W3850 & Pahala \\
\hline p2b16 & 540 & 2 & Moa'ula flow & 9P77C & W5153 & Pahala \\
\hline p2b16 & 540 & 2 & Moa'ula flow & L-91-525 & W6470 & Pahala \\
\hline p2b16 & 540 & 2 & Moa'ula flow & L-93-545 & USGS3475 & Punaluu \\
\hline p2b16 & 540 & 2 & Moa'ula flow & $\mathrm{L}-93-596^{10}$ & USGS3478 & Punaluu \\
\hline p2b16 & 540 & 2 & Moa'ula flow & L-93-639 ${ }^{10}$ & WW347 & Punaluu \\
\hline a2a18 & 349 & 2 & Kauhiuhi Maluikeao flow & L-86-330 & W6004 & Kipuka Pakekake \\
\hline p2g22 & 883 & 2 & Upper Strip Road flow & L-78-02 & W4116 & Kipuka Pakekake \\
\hline p2g22 & 883 & 2 & Upper Strip Road flow & L-86-02 & W5815 & Kilauea Crater \\
\hline p2g22 & 883 & 2 & Upper Strip Road flow & PUD- $136^{10}$ & W4579 & Puu Ulaula \\
\hline- & NAS & 2 & - & L-91-148 & W6461 & Wood Valley \\
\hline a3a1 & 295 & 3 & Red Cone flow & $77 \mathrm{~L}-56^{10}$ & W4161 & Keaiwa Reservoir \\
\hline a3a1 & 295 & 3 & Red Cone flow & $77 \mathrm{~L}-57^{10}$ & W4163 & Keaiwa Reservoir \\
\hline a3a1 & 295 & 3 & Red Cone flow & $\mathrm{L}-91-186^{10}$ & W6349 & Keaiwa Reservoir \\
\hline a3a2 & 889 & 3 & Eastern Ka'ōiki Pali flow & L-77-41 & W3876 & Kilauea Crater \\
\hline a3a2 & 889 & 3 & Eastern $\mathrm{Ka}^{‘}$ ōiki Pali flow & L-80-81 & W4831 & Kilauea Crater \\
\hline a3a3 & 637 & 3 & Nīnole flow & L-93-626 ${ }^{10}$ & USGS3479 & Punaluu \\
\hline p3e4 & 345 & 3 & Cow Pasture picrite flow & 77L-03 & W3841 & Wood Valley \\
\hline p3e4 & 345 & 3 & Cow Pasture picrite flow & 77L-12 & W3845 & Wood Valley \\
\hline p3e4 & 345 & 3 & Cow Pasture picrite flow & L-92-137 & WW322 & Wood Valley \\
\hline p4a1 & 892 & 4 & 'Ōhaikea flow & L-81-18 & W5086 & Kilauea Crater \\
\hline ts & 959 & 5 & Southern tephra & L-91-624 ${ }^{10}$ & W6477 & Keaiwa Reservoir \\
\hline ts & 959 & 5 & Southern tephra & 77L-05 & W3844 & Wood Valley \\
\hline m5a1 & 399 & 5 & Halfway House flow & GAM & W1046 & Wood Valley \\
\hline m5a1 & 399 & 5 & Halfway House flow & 77L-05 & W3844 & Wood Valley \\
\hline m5a1 & 399 & 5 & Halfway House flow & L-92-149 & WW848 & Wood Valley \\
\hline p8e1 & 962 & 8 & Palakea Flat flow & KUc- $177^{10}$ & W4991 & Kulani \\
\hline p9h1 & 395 & 9 & Halfway House Kīpuka flow & MJ-87-C6 & W6038 & Wood Valley \\
\hline p9h1 & 395 & 9 & Halfway House Kīpuka flow & L-80-163 & W4821 & Wood Valley \\
\hline p9g2 & 978 & 9 & $\mathrm{Pu}^{6} u^{6} u l a^{6}$ ula flow & $77 \mathrm{~L}-10$ & W3853 & Kilauea Crater \\
\hline p9g2 & 978 & 9 & $\mathrm{Pu}^{\prime} \mathrm{u}^{\prime}$ ula'ula flow & L-80-138 & W4803 & Kilauea Crater \\
\hline m10b1 & 383 & 10 & Ka‘ū High School flow & L-93-101 & WW339 & Pahala \\
\hline m10b1 & 383 & 10 & Ka'ū High School flow & L-91-50 & AA7656 & Pahala \\
\hline m10b1 & 383 & 10 & Ka‘ū High School flow & L-91-680 & W6482 & Pahala \\
\hline m10b1 & 383 & 10 & Ka'ū High School flow & $\mathrm{L}-93-533^{10}$ & WW343 & Punaluu \\
\hline
\end{tabular}




\begin{tabular}{|c|c|c|c|c|c|c|c|c|c|}
\hline $\begin{array}{l}\text { Latitude }^{4} \\
\text { (degree) }\end{array}$ & $\begin{array}{c}\text { Longitude }^{4} \\
\text { (degree) }\end{array}$ & $\begin{array}{l}\text { Elev } \\
\text { (ft) }\end{array}$ & $\begin{array}{c}\text { Age }^{5} \\
\text { (yr B.P.) }\end{array}$ & $\begin{array}{l}\text { S.D. } \\
(y r)\end{array}$ & $\begin{array}{c}\text { Weighted average } \\
\text { (yr B.P.) }\end{array}$ & $\begin{array}{l}\text { S.D. }^{6} \\
(\mathrm{yr})\end{array}$ & Quality $^{7}$ & $\begin{array}{c}\text { Age range } \\
\text { (calendar years) }\end{array}$ & Source $^{9}$ \\
\hline 19.33998 & -155.52340 & 6,800 & 1,650 & 60 & 1,622 & 23 & + & 254 to 541 & 3 \\
\hline 19.66731 & -155.11106 & 660 & 1,740 & 100 & 1,638 & 32 & + & 78 to 535 & 2 \\
\hline 19.64163 & -155.16607 & 1,740 & 1,585 & 40 & 1,638 & 32 & + & 398 to 564 & 2 \\
\hline 19.52973 & -155.35102 & 6,440 & 1,690 & 70 & 1,638 & 32 & + & 143 to 539 & 2 \\
\hline 19.67363 & -155.11970 & 800 & 2,000 & 250 & 1,638 & 32 & 0 & -748 to 558 & 2 \\
\hline 19.67356 & -155.11978 & 800 & 2,070 & 250 & 1,638 & 32 & 0 & -769 to 428 & 2 \\
\hline 19.36608 & -155.37766 & 3,020 & 1,640 & 150 & - & - & 0 & 71 to 661 & 2 \\
\hline 19.27681 & -155.47994 & 2,370 & 1,700 & 80 & 1,708 & 50 & 0 & 138 to 535 & 3 \\
\hline 19.27368 & -155.48965 & 2,700 & 1,820 & 80 & 1,708 & 50 & + & 26 to 396 & 3 \\
\hline 19.18410 & -155.48308 & 450 & 1,810 & 80 & 1,824 & 19 & + & 28 to 414 & 1,2 \\
\hline 19.16078 & -155.49543 & 175 & 1,500 & 70 & 1,824 & 19 & 0 & 415 to 662 & 2 \\
\hline 19.18386 & -155.48119 & 420 & 1,830 & 30 & 1,824 & 19 & + & 86 to 317 & 3 \\
\hline 19.19656 & -155.51834 & 1,625 & 1,780 & 40 & 1,824 & 19 & + & 130 to 380 & 3 \\
\hline 19.18940 & -155.51213 & 1,320 & 1,885 & 30 & 1,824 & 19 & + & 34 to 227 & 3 \\
\hline 19.19358 & -155.50552 & 1,340 & 2,030 & 80 & 1,824 & 19 & + & -348 to 130 & 3 \\
\hline 19.44875 & -155.43949 & 7,070 & 1,910 & 120 & - & - & + & -193 to 390 & 3 \\
\hline 19.48293 & -155.38247 & 6,280 & 1,840 & 60 & 1,993 & 43 & + & 32 to 336 & 1,2 \\
\hline 19.44964 & -155.34664 & 4,770 & 2,270 & 130 & 1,993 & 43 & + & -761 to -6 & 3 \\
\hline 19.50618 & -155.39308 & 7,260 & 2,120 & 70 & 1,993 & 43 & + & -366 to 16 & 2 \\
\hline 19.30584 & -155.48280 & 3,680 & 2,000 & 85 & - & - & + & -340 to 218 & 3 \\
\hline 19.29351 & -155.56723 & 6,760 & 2,000 & 70 & 2,072 & 37 & + & -195 to 131 & 1,2 \\
\hline 19.29749 & -155.55876 & 6,680 & 1,980 & 80 & 2,072 & 37 & + & -195 to 227 & 1,2 \\
\hline 19.30734 & -155.58595 & 7,520 & 2,150 & 50 & 2,072 & 37 & + & -364 to -45 & 3 \\
\hline 19.45210 & -155.29076 & 4,100 & 2,190 & 70 & 2,265 & 49 & + & -392 to -57 & 1,2 \\
\hline 19.45208 & -155.29081 & 4,120 & 2,340 & 70 & 2,265 & 49 & + & -752 to -205 & 2 \\
\hline 19.16975 & -155.55796 & 1,920 & 2,365 & 30 & - & - & + & -535 to -386 & 3 \\
\hline 19.33072 & -155.40527 & 2,600 & 2,950 & 80 & 2,826 & 32 & + & -1405 to -920 & 1,2 \\
\hline 19.36942 & -155.39613 & 3,550 & 2,880 & 70 & 2,826 & 32 & + & -1291 to -843 & 1,2 \\
\hline 19.33486 & -155.45218 & 3,540 & 2,890 & 60 & 2,826 & 32 & + & -1287 to -903 & 3 \\
\hline 19.42062 & -155.34473 & 4,080 & 3,630 & 80 & - & - & + & -2204 to -1758 & 2 \\
\hline 19.33998 & -155.52340 & 6,800 & 4,020 & 60 & 4,135 & 49 & + & -2856 to -2352 & 3 \\
\hline 19.36153 & -155.38214 & 3,020 & 4,340 & 80 & 4,135 & 49 & + & -3328 to -2710 & 3 \\
\hline 19.36142 & -155.38388 & 2,990 & 4,030 & 350 & 4,378 & 42 & + & -3515 to -1639 & 2 \\
\hline 19.36307 & -155.38391 & 3,020 & 4,340 & 80 & 4,378 & 42 & + & -3335 to -2705 & 1,2 \\
\hline 19.36028 & -155.38182 & 2,920 & 4,400 & 50 & 4,378 & 42 & + & -3327 to -2905 & 3 \\
\hline 19.50935 & -155.32389 & 5,440 & 7,960 & 110 & - & - & + & -7174 to -6593 & 2 \\
\hline 19.36164 & -155.38537 & 3,140 & 8,370 & 200 & 8,520 & 82 & + & -7939 to -6780 & 3 \\
\hline 19.36102 & -155.38548 & 3,050 & 8,550 & 90 & 8,520 & 82 & + & -7818 to -7361 & 1 \\
\hline 19.41579 & -155.33550 & 3,680 & 8,550 & 100 & 8,645 & 71 & + & -7865 to -7379 & 1,2 \\
\hline 19.43091 & -155.32599 & 4,000 & 8,740 & 100 & 8,645 & 71 & + & -8207 to -7581 & 2 \\
\hline 19.20785 & -155.47697 & 980 & 8,720 & 70 & 9,121 & 46 & & -8166 to -7589 & 3 \\
\hline 19.20782 & -155.47704 & 975 & 8,955 & 115 & 9,121 & 46 & + & -8425 to -7715 & 3 \\
\hline 19.20509 & -155.48798 & 1,160 & 9,960 & 170 & 9,121 & 46 & + & -10171 to -8878 & 3 \\
\hline 19.21680 & -155.50466 & 2,115 & 9,540 & 80 & 9,121 & 46 & + & -9213 to -8653 & 3 \\
\hline
\end{tabular}


Table 2. Radiocarbon ages of samples from the central-southeast flank of Mauna Loa volcano, Island of Hawai $i$, Hawaii.-Continued [All ages are reported in radiocarbon years before present (yr B.P., before the calendar year datum of A.D. 1950). Materials dated include charcoal, roots, twigs, vegetative litter, or unaltered wood (rarely). See figure 1 for quadrangle locations]

\begin{tabular}{|c|c|c|c|c|c|c|}
\hline Unit label $^{1}$ & FID $^{2}$ & $\begin{array}{l}\text { Age }^{1} \\
\text { group }\end{array}$ & Unit name & Field No. & Lab No. ${ }^{3}$ & $\begin{array}{c}\text { Quadrangle name } \\
(1: 24,000)\end{array}$ \\
\hline p10c2 & 742 & 10 & Lae'opuhili flow & 9P70C1 & W4419 & Pahala \\
\hline p10c2 & 742 & 10 & Lae'opuhili flow & $78 \mathrm{~L}-18^{10}$ & W4201 & Punaluu \\
\hline ts & 959 & 10 & Southern tephra & 77L-07 & W3840 & Kilauea Crater \\
\hline p10a3 & 338 & 10 & Flow 338 & L-92-668 & WW326 & Wood Valley \\
\hline $\mathrm{NAS}^{11}$ & NAS & 11 & - & L-92-606 & WW325 & Pahala \\
\hline a11a2 & 388 & 11 & Pā'au'au flow & L-91-55 & W7657 & Pahala \\
\hline p11b3 & 386 & 11 & Meyer Camp flow & L-91-46 & W6423 & Pahala \\
\hline$a 13 b 2$ & 384 & 13 & Flow 384 & L-91-564R & WW240 & Pahala \\
\hline$a 13 b 2$ & 384 & 13 & Flow 384 & L-91-548 ${ }^{10}$ & W6471 & Punaluu \\
\hline a13b2 & 384 & 13 & Flow 384 & L-92-582 & USGS3471 & Pahala \\
\hline $\mathrm{NAS}^{11}$ & NAS & 13 & - & L-92-588 & USGS3473 & Pahala \\
\hline NAS $^{11}$ & NAS & 13 & - & L-92-576 & USGS3470 & Pahala \\
\hline a13f3 & 735 & 13 & Lava flow of Hi'onamoa Gulch & $\mathrm{L}-91-555^{10}$ & WW321 & Punaluu \\
\hline z13a4 & 389 & 13 & Pāhala Ash & L-92-582D & USGS3472 & Pahala \\
\hline
\end{tabular}

'See table 3 (sheet 1) for explanation of unit labels and definition of age groups.

2Unique, three-digit flow identification number assigned to each mapped surface-flow unit correlates with database (https://doi.org/10.3133/sim2932B).

${ }^{3}$ Initial letter(s) identifies analytical laboratory: AA, University of Arizona, Tucson, Ariz.; SUERC, NERC radiocarbon laboratory, Kilbride, Scotland, UK; USGS, U.S. Geological Survey ${ }^{14} \mathrm{C}$ laboratory, Menlo Park, Calif.; W, U.S. Geological Survey ${ }^{14} \mathrm{C}$ laboratory, Reston, Va. Initial letter(s) for Accelerator Mass Spectrometer (AMS) ages: A, WW, SUERC.

4Projection: decimal degrees. Datum: WGS84.

${ }^{5}$ Calibrated ages are for two standard deviations.

${ }^{6}$ Weighted avg., each age is weighted by the inverse of its variance before averaging (for example, Taylor 1982). A variance is reported as one standard deviation, in years.

'Quality: + , age considered meaningful; 0 , age probably meaningful but accuracy may be poorer than indicated by the reported precision.

${ }^{8}$ Each age was calibrated to calendar years using CALIB 6.0 Radiocarbon Calibration Program (Stuiver and others, 2005); calibrated ages are for two standard deviations. Entire age range of calendar ages is possible for a given sample. Unspecified ages, A.D.; negative (-) ages, B.C.

${ }^{9}$ Sources: 1, Kelley and others, 1979; 2, Rubin and others, 1987; 3, this study.

${ }^{10}$ Radiocarbon sample collected outside of mapped area: Kulani, Piihonua, and Puu Ulaula quadrangles (SIM 2932-A); Punaluu quadrangle (SIM 2932-C), and Keaiwa Reservoir quadrangle (SIM 2932-D).

"NAS, flows not found at surface are exposed in drainages, fault scarps, and (or) sea cliffs.

${ }^{12} \mathrm{NAC}$, not able to calibrate ${ }^{14} \mathrm{C}$ age because too old for CALIB program. 


\begin{tabular}{|c|c|c|c|c|c|c|c|c|c|}
\hline $\begin{array}{l}\text { Latitude }^{4} \\
\text { (degree) }\end{array}$ & $\begin{array}{c}\text { Longitude }^{4} \\
\text { (degree) }\end{array}$ & $\begin{array}{l}\text { Elev } \\
\text { (ft) }\end{array}$ & $\begin{array}{c}\text { Age }^{5} \\
\text { (yr B.P.) }\end{array}$ & $\begin{array}{l}\text { S.D. } \\
\text { (yr) }\end{array}$ & $\begin{array}{c}\text { Weighted average } \\
\text { (yr B.P.) }\end{array}$ & $\begin{array}{l}\text { S.D. }^{6} \\
(\mathrm{yr})\end{array}$ & Quality $^{7}$ & $\begin{array}{c}\text { Age range } \\
\text { (calendar years) }\end{array}$ & Source $^{9}$ \\
\hline 19.15966 & -155.49475 & 210 & 9,300 & 130 & 9,218 & 79 & + & -9118 to -8261 & 2 \\
\hline 19.20450 & -155.53528 & 2,140 & 9,170 & 100 & 9,218 & 79 & + & -8694 to -8227 & 1,2 \\
\hline 19.41515 & -155.34106 & 3,750 & 9,500 & 140 & - & - & + & -9252 to -8471 & 1,2 \\
\hline 19.28410 & -155.42982 & 2,120 & 9,680 & 70 & - & - & + & -9279 to -8830 & 3 \\
\hline 19.23768 & -155.48886 & 1,980 & 10,010 & 70 & - & - & + & -9858 to -9301 & 3 \\
\hline 19.21949 & -155.48103 & 1,380 & 10,030 & 85 & - & - & + & -10009 to -9306 & 3 \\
\hline 19.21947 & -155.48614 & 1,460 & 10,600 & 150 & - & - & + & -10908 to -10151 & 3 \\
\hline 19.19938 & -155.48648 & 990 & 25,000 & 460 & 25,768 & 188 & + & $\mathrm{NAC}^{12}$ & 3 \\
\hline 19.20977 & -155.49981 & 1,610 & 25,570 & 600 & 25,768 & 188 & - & $\mathrm{NAC}^{12}$ & 3 \\
\hline 19.18879 & -155.48278 & 575 & 25,970 & 220 & 25,768 & 188 & + & $\mathrm{NAC}^{12}$ & 3 \\
\hline 19.20514 & -155.49645 & 1,400 & 26,450 & 120 & 26,532 & 88 & + & $\mathrm{NAC}^{12}$ & 3 \\
\hline 19.20026 & -155.48893 & 1,060 & 26,630 & 130 & 26,532 & 88 & + & $\mathrm{NAC}^{12}$ & 3 \\
\hline 19.20966 & -155.49983 & 1,605 & 28,140 & 590 & - & - & + & $\mathrm{NAC}^{12}$ & 3 \\
\hline 19.18873 & -155.48278 & 575 & 31,020 & 310 & - & - & + & $\mathrm{NAC}^{12}$ & 3 \\
\hline
\end{tabular}

